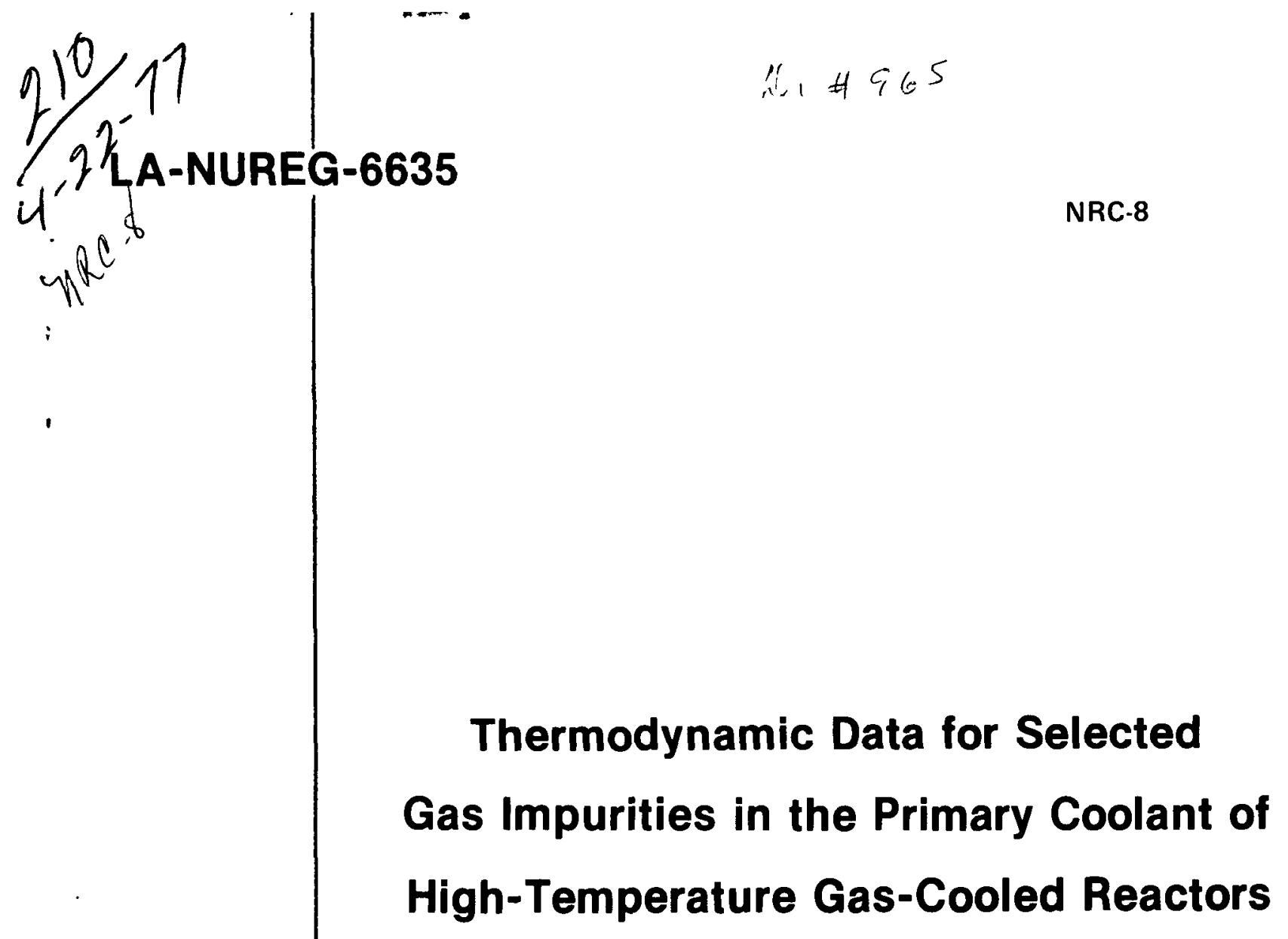

Issued: April 1977

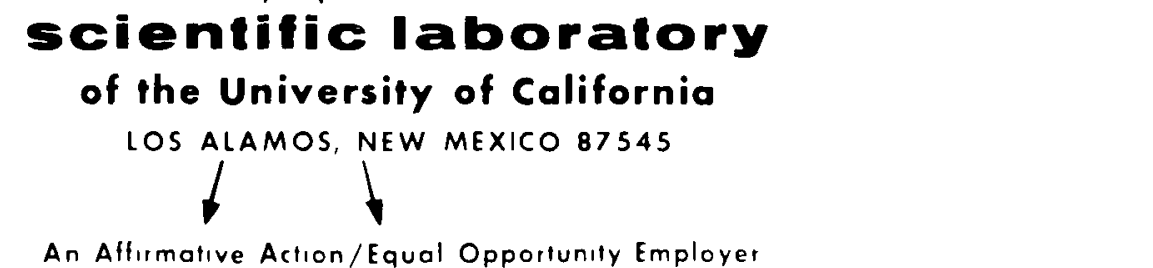


This work was performed under the auspices of the US Nuclear Regulatory Commission's Office of Nuclear Regulatory Research, Division of Reactor

Safety Research.

Printed in the United States of America. Available from

National Technical Information Service

U.S. Department of Commerce

5285 Port Royal Road

Springfield, VA 22161

Price: Printed Copy $\$ 4.00$ Microfiche $\$ 3.00$

NOTICE

This report was prepared as an account of work sponsored by the United States Govemment. Neither the United States nor the United States Nuclear Regulatory Commission, nor any of their employees, nor any of their contractors, subcontractors, or their employees, makes any warranty, express or implied, or assumes any legal liability or responsibility for the accuracy, completeness or usefulness of any information, apparatus, product or process disclosed, or represents that its use would not infringe privately owned rights. 


\section{DISCLAIMER}

This report was prepared as an account of work sponsored by an agency of the United States Government. Neither the United States Government nor any agency Thereof, nor any of their employees, makes any warranty, express or implied, or assumes any legal liability or responsibility for the accuracy, completeness, or usefulness of any information, apparatus, product, or process disclosed, or represents that its use would not infringe privately owned rights. Reference herein to any specific commercial product, process, or service by trade name, trademark, manufacturer, or otherwise does not necessarily constitute or imply its endorsement, recommendation, or favoring by the United States Government or any agency thereof. The views and opinions of authors expressed herein do not necessarily state or reflect those of the United States Government or any agency thereof. 


\section{DISCLAIMER}

Portions of this document may be illegible in electronic image products. Images are produced from the best available original document. 
R. C. Feber

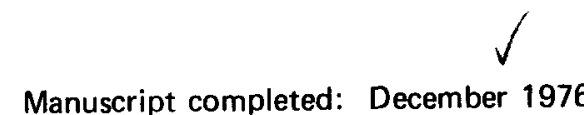
Issued: April 1977 


\title{
THERMODYNAMIC DATA FOR SELECTED \\ GAS IMPURITIES IN THE PRIMARY COOLANT OF HIGH-TEMPERATURE GAS-COOLED REACTORS
}

by

\author{
R. C. Feber
}

\begin{abstract}
The literature of thermodynamic data for selected fission-product species is reviewed and supplemented in support of complex chemical equilibrium calculations applied to fission-product distributions in the primary coolant of high-temperature gas-cooled reactors. Thermodynamic functions and heats and free energies of formation are calculated and tabulated to $3000 \mathrm{~K}$ for $\mathrm{CsI}(\mathrm{s}, \ell, \mathrm{g}), \mathrm{Cs}_{2} \mathrm{I}_{2}(\mathrm{~g}), \mathrm{CH}_{3} \mathrm{I}(\mathrm{g}), \mathrm{COI}_{2}(\mathrm{~g})$, and $\mathrm{CsH}(\mathrm{g})$.
\end{abstract}

\section{INTRODUCTION}

The impurity content of the primary coolant of a high-temperature gas-cooled reactor (HTGR) has two important aspects. The first has to do with the interaction of the impurities with the graphite core and structural members and, of course, has been the subject of much experimental and calculational effort. The second aspect is the effect of a variable distribution among impurity species on the form in which fission products may be present in the primary coolant loop or under accident conditions. In this context, impurity species refer to those resulting from graphite-steam reaction. In addition, compound formation may be possible among fission-product species themselves; for example, between cesium and iodine.

The computer code QUIL has been used recently to solve complex chemical equilibrium distributions in HTGR environments. ${ }^{1}$ The equilibrium distribution of cesium among its vapor species and a number of other impurity distributions were calculated for a range of normal and abnormal reactor coolant conditions. Many of the thermodynamic data required for these calculations were available in the JANAF tables, ${ }^{2}$ but others were not. In this report we describe the sources and treatment of data that we found in the literature and which we used to compile the additional thermodynamic data that are tabulated. Because we decided to carry all tables to $3000 \mathrm{~K}$, we extended the data from the literature to that temperature in two cases. Tables are given for $\mathrm{CsI}(\mathrm{s}, \ell, \mathrm{g}), \mathrm{Cs}_{\mathbf{2}} \mathrm{I}_{\mathbf{2}}(\mathrm{g}), \mathrm{CH}_{8} \mathrm{I}(\mathrm{g}), \mathrm{COI}_{2}(\mathrm{~g})$, and $\mathrm{CsH}(\mathrm{g})$. Behrens has recently recalculated thermodynamic data for $\mathrm{Cs}_{2}(\mathrm{~g})$ on the basis of a new value for $\mathrm{r}_{\mathrm{e}}{ }^{\mathrm{s}}$ 


\section{THERMODYNAMIC DATA FOR THE CESIUM-IODINE SYSTEM}

\section{A. Low-Temperature Heat Capacity of CsI(s)}

The low-temperature heat capacity of CsI(s) has been measured at 54 points between 13.91 and $298.39 \mathrm{~K}$ (Ref. 4), at 189 points between 1.50 and $299.21 \mathrm{~K}$ (Ref. 5 ), and at 17 points between 2.13 and $10.00 \mathrm{~K}$ (Ref. 6). Table I shows thermodynamic quantities at $298.15 \mathrm{~K}$ calculated by the authors of Refs. 4-6 as well as our recalculation of their data by computer smoothing and numerical integration. From the last calculation of Table I we use $C_{p, 298}^{\circ}=12.590$ gibbs $/ \mathrm{mole}$ and $\mathrm{S}_{\mathbf{2} 9 \mathbf{0}}^{\mathbf{o}}=29.200 \mathrm{gibbs} / \mathrm{mole}$.

\section{B. High-Temperature Heat Content of $\mathrm{CsI}(\mathrm{s}, \ell)$}

Identical high-temperature heat content data (obtained with an ice calorimeter) between 369.3 and $1172.2 \mathrm{~K}$ are reported in Refs. 7 and 8 , but these data are treated in different ways. The problem is that without constraints the heat content data do not extrapolate to near the origin (to zero at $273.15 \mathrm{~K}$ ) nor do they give an extrapolated $C_{p}^{o}$ at room temperature that is close to the $C_{p}^{o}$ from low-temperature heat capacity measurements.

In both papers the heat content data for the solid are fitted to an equation of the form

$$
\mathrm{H}_{\mathrm{T}}^{\circ}-\mathrm{H}_{273}^{\circ}=\mathrm{a}+\mathrm{b} \mathrm{T}+\mathrm{cT}^{2}+\mathrm{d} / \mathrm{T} \text {. }
$$

In Ref. 8 the data are forced through the origin, from which fit $\mathrm{C}_{\mathrm{p}, 208}^{o}=11.899$ gibbs $/ \mathrm{mole}$. Also, in Ref. 8 the heat content data for the liquid are fitted to an equation of the form

$$
\mathrm{H}_{\mathrm{T}}-\mathrm{H}_{278}^{\circ}=\mathrm{a}+\mathrm{bT}+\mathrm{cT}^{2} \text { (without constraints). }
$$

From the two fits, at a melting point of $899 \mathrm{~K}, \mathrm{C}_{\mathrm{p}}^{\circ}(\mathrm{s})=16.015$ and $\mathrm{C}_{\mathrm{p}}^{\circ}(\ell)=14.073 \mathrm{gibbs} / \mathrm{mole}$ $\left(\Delta \mathrm{H}_{\text {fuation }}=6170 \mathrm{cal} / \mathrm{mole}\right)$. It is unlikely that $\mathrm{C}_{\mathrm{p}, \mathrm{mp}}^{o}(\mathrm{~s})$ is greater than $\mathrm{C}_{\mathrm{p} \text {,mp }}^{o}(\ell)$.

In Ref. 7, the fit to the solid heat content data had the additional constraint that $C_{p, 200}^{o}=12.39$ gibbs/mole, which produces a minimum in the heat capacity-temperature curve between 273.15 and $370 \mathrm{~K}$. The melting point is taken as $907 \mathrm{~K}$ and, although the same experimental data for the liquid heat content are fitted to an equation of the same form as in Ref. 8, the equations for the fits are not the same. From Ref. $7, \Delta \mathrm{H}_{\text {fuation }}=5979 \mathrm{cal} / \mathrm{mole}$ at $907 \mathrm{~K}$.

On the assumption that the heat content data are not sufficiently precise to warrant a $d / T$ term for the solid or a $\mathrm{cT}^{2}$ term for the liquid, we recalculated a fit for the solid data to $\mathrm{H}^{\circ}-\mathrm{H}_{27 \mathrm{~s}}^{\mathrm{o}}$ $=\mathrm{a}+\mathrm{bT}+\mathrm{cT}^{2}$ (without constraints) and for the liquid data to $\mathrm{H}_{\mathrm{T}}-\mathrm{H}_{27 \mathrm{~s}}^{\mathrm{o}}=\mathrm{a}+\mathrm{bT}$ (a constant heat capacity). The equation for the solid extrapolated to a respectable $-49 \mathrm{cal} / \mathrm{mole}$ at $273.15 \mathrm{~K}$, compared with $-821 \mathrm{cal} / \mathrm{mole}$ if the $\mathrm{d} / \mathrm{T}$ term was retained and an unconstrained fit was made.

With our fits, $\mathrm{C}_{\mathrm{p}, 298}^{o}(\mathrm{~s})=12.140 \mathrm{gibbs} / \mathrm{mole} ; \mathrm{C}_{\mathrm{p}, 809}^{o}(\mathrm{~s})=15.793 \mathrm{gibbs} / \mathrm{mole} ; \mathrm{C}_{\mathrm{p}, \text { ese }}^{o}(\ell)=16.448$ gibbs $/$ mole; and $\Delta \mathrm{H}_{\text {qusion }}=5947 \mathrm{cal} / \mathrm{mol}$. We take $\mathrm{C}_{\mathrm{p}}^{\mathrm{o}}(\ell)$ to be $16.45 \mathrm{gibbs} / \mathrm{mole}$ and use $5950 \mathrm{cal} /$ mole for $\Delta H_{\text {fusion }}$ at a melting point of $899 \mathrm{~K} .^{\circ}$ We do not reference other measurements of the melting point, which range from $894-907 \mathrm{~K}$.

From recent predictions of $\mathrm{C}_{p}^{\circ} \mathrm{s}$ for a number of molten alkali metal halides using a model of the fused salts, ${ }^{10} \mathrm{C}_{\mathrm{p}}^{\circ} \mathrm{CsCl}(\ell)=16.4$ gibbs $/$ mole and $\mathrm{C}_{\mathrm{p}}^{\circ} \mathrm{CsI}(\ell)=14.8 \mathrm{gibbs} / \mathrm{mole}$. The heat of fusion of CsI has also been reported as $5640 \pm 100 \mathrm{cal} / \mathrm{mole}^{11}$ and $6580 \pm 200 \mathrm{cal} / \mathrm{mole} .^{12}$ According to the JANAF tables, ${ }^{2} \mathrm{C}_{\mathrm{p}}^{\circ} \mathrm{CsF}(\ell)=17.7 \mathrm{gibbs} / \mathrm{mole}$ and $\mathrm{C}_{\mathrm{p}}^{\circ} \mathrm{CsCl}(\ell)=18.5 \mathrm{gibbs} / \mathrm{mole}$. 
We join the low-temperature heat capacity data smoothly to our fit of the high-temperature heat content data of Refs. 7 and 8 and calculate the thermodynamic functions $C_{p}^{o}, S_{T}^{o},-\left(F_{T}^{o}-\right.$ $\left.\mathrm{H}_{208}^{\circ}\right) / T$, and $\mathrm{H}_{\mathrm{T}}^{\circ}-\mathrm{H}_{200}^{\circ}$ for CsI $(s, \ell)$ given in Table II.

\section{Heat of Formation of CsI(s)}

In NBS Circular $500,{ }^{\circ} \Delta \mathrm{H}^{9}, 28 \mathrm{CsI}(\mathrm{s})$ was listed as $-80.5 \pm 2.5 \mathrm{kcal} / \mathrm{mole}$. This value was later corrected $^{18,14}$ to $-83.9 \mathrm{kcal} / \mathrm{mole}$ to be consistent with a more recent ${\overline{\Delta \mathrm{H}^{\circ}}}^{\circ}$ for $\mathrm{Cs}^{+}$. A still more recent value of $-81.1 \mathrm{kcal} / \mathrm{mole}$ has been reported for $\Delta \mathrm{H}_{1,288}^{\circ} \mathrm{CsI}(\mathrm{s})$ from heat-of-solution measurements. ${ }^{16}$ This last quantity was in turn recalculated ${ }^{16}$ to $-83.47 \pm 0.3 \mathrm{kcal} / \mathrm{mole}$ using reference thermodynamic data for solutions from the NBS. ${ }^{17} \mathrm{We}$ use the value of $-83.9 \mathrm{kcal} / \mathrm{mole}$ because a more negative value is preferred, for reasons to be given later.

Table III contains values of $\Delta \mathrm{H}_{\mathrm{f}}^{\circ}$ and $\Delta \mathrm{G}_{\mathrm{f}}^{o}$ for $\mathrm{CsI}(\mathrm{s}, \ell)$ as a function of temperature to $3000 \mathrm{~K}$.

\section{Thermodynamic Functions for $\mathrm{CsI}(\mathrm{g})$ and $\mathrm{Cs}_{2} \mathrm{I}_{2}(\mathrm{~g})$}

Vibrational and rotational constants for $\operatorname{CsI}(\mathrm{g})$ available since $1950^{18}$ are given in Refs. 19-23. We used the constants for the ${ }^{1} \Sigma$ ground state given in Ref. 23 . Constants included in the calculations and their values in $\mathrm{cm}^{-1}$ are:

$$
\begin{aligned}
\omega_{\mathrm{e}} & =119.178 \\
\omega_{\mathrm{e}} \mathrm{X}_{\mathrm{e}} & =0.2505 \\
\omega_{\mathrm{e}} \mathrm{y}_{\mathrm{e}} & =0 .
\end{aligned}
$$

$$
\begin{aligned}
\mathrm{B}_{\mathrm{e}} & =2.36273 \times 10^{-2} \\
\alpha_{\mathrm{e}} & =6.82625 \times 10^{-6} \\
\gamma_{\mathrm{e}} & =4.893 \times 10^{-8} \\
\mathrm{D}_{\mathrm{e}} & =3.71464 \times 10^{-8}
\end{aligned}
$$

Our method of calculation was based on the approximation to level summation described by Mayer and Mayer. ${ }^{24}$ Presumably, slightly more accurate functions could be calculated using direct summation of levels with cut-off of rotational and vibrational levels. ${ }^{25,28}$ The results of our calculations for CsI $(\mathrm{g})$ are given in Table IV.

The thermodynamic functions for $\mathrm{Cs}_{2} \mathrm{I}_{2}(\mathrm{~g})$ given in Table $\mathrm{V}$ were calculated with the harmonic oscillator, rigid rotor approximation and the molecular parameters estimated in Ref. 27:

\section{Frequencies}

$$
\begin{aligned}
& \nu_{1}=69 \mathrm{~cm}^{-1} \\
& \nu_{2}=58 \\
& \nu_{3}=69 \\
& \nu_{4}=33 \\
& \nu_{6}=77 \\
& \nu_{6}=83
\end{aligned}
$$

\section{Moments of Inertia}

$$
\begin{aligned}
& \mathrm{I}_{\mathrm{A}}=3088.3 \times 10^{-40} \mathrm{~g} \mathrm{~cm}^{2} \\
& \mathrm{I}_{\mathrm{B}}=2359.3 \\
& \mathrm{I}_{\mathrm{C}}=5447.6 \\
& \sigma=4
\end{aligned}
$$

Molecular constants also have been estimated for a number of other alkali halide dimers. ${ }^{28-30}$

\section{E. Heats of Formation of $\mathrm{CsI}(\mathrm{g})$ and $\mathrm{Cs}_{2} \mathrm{I}_{2}(\mathrm{~g})$}

We need to know the value of $\Delta \mathrm{H}_{\text {, 28s }}^{\circ}$ for $\mathrm{CsI}(\mathrm{g})$ and for $\mathrm{Cs}_{2} \mathrm{I}_{2}(\mathrm{~g})$. The former value can be obtained from a Born-Haber cycle by adding $\Delta \mathrm{H}_{\mathrm{r}, 289}^{\circ} \mathrm{CsI}(\mathrm{s})$ and $\lrcorner \mathrm{H}_{\mathrm{subl}, 298}^{\circ}$ to the monomer (from 
vapor pressure measurements corrected, if necessary, for the partial pressure of the dimer). The latter value can be obtained by knowing, in addition, the dissociation energy $\left(\mathrm{Cs}_{2} \mathrm{I}_{2}(\mathrm{~g}){ }_{2} \mathrm{Cs}(\mathrm{g})\right.$ $+2 \mathrm{I}(\mathrm{g}))$ or the heat of dimerization $\left(\mathrm{Cs}_{2} \mathrm{I}_{2}(\mathrm{~g}) \stackrel{\Delta \mathrm{H}_{2}}{2} \mathrm{CsI}(\mathrm{g})\right)$. There may also be other sources of information for $\Delta \mathrm{H}_{\text {,20s }} \mathrm{CsI}(\mathrm{g})$ that do not depend on knowledge of the vapor pressure and that could therefore be used as a check. Because of experimental uncertainties, a completely unambiguous set of heats may not be achievable, but a reasonable, self-consistent set within those uncertainties should be.

1. Vapor Pressure of CsI $(8, \ell)$. Sources of vapor pressure data for CsI are given in Table VI. Literature on the amount of dimers (and, in some cases, trimers) in the vapors of the alkali halides is extensive. The general conclusion is that as the mass of the cation increases, the amount of polymeric species in the vapor decreases. Thus cesium halide vapors contain relatively small amounts of the dimer. In general, as the temperature increases, the proportion of dimer with respect to the monomer could increase or decrease, depending on the relative magnitudes of the heats of sublimation to the monomer and the dimer.

Pre-1961 literature for all alkali halides was worked into thermodynamic data by Brewer and Brackett, ${ }^{14}$ and data for many of the cesium halides (but not CsI) are also given in the JANAF tables. $^{2}$

We calculated the heats of sublimation at $298.15 \mathrm{~K}$ for CsI from the data sources of Table VI, and results are given in Table VII. The possible presence of the dimer has been ignored for the moment, and the uncertainties are standard deviations.

With one exception, which derives from an equation for the data, all third-law heats are lower than second-law heats. Aside from systematic experimental errors, such a prevailing variation could be caused by too small a $\Delta$ (free-energy function) for the vaporization process, or by the presence of dimer in the vapor, or by a combination of effects.

Before looking further at the evidence for the presence of dimers in CsI vapors, we will mention two sources for $\Delta \mathrm{H}_{i, 29 s}^{\circ} \mathrm{CsI}(\mathrm{g})$ that do not depend on a Born-Haber cycle. From them we can calculate $\Delta \mathrm{H}_{\mathrm{r}, 298} \mathrm{CsI}(\mathrm{s})$ by using a preliminary value from Table VII of $46.4 \mathrm{kcal} / \mathrm{mole}$ for $\Delta \mathrm{H}_{\mathrm{subl}, 208} \mathrm{CsI}(\mathrm{s})$ to the monomer. To show the reasonableness of the $\Delta \mathrm{H}_{\mathrm{f}, 208}^{\circ} \mathrm{CsI}(\mathrm{s})$ value given in Sec. II-C, we will go through the exercise but will not make further use of data from these two sources. The effect of dimers in the vapor will be to increase $\Delta \mathrm{H}_{\mathrm{subl}, 208}^{\circ} \mathrm{CsI}(\mathrm{s})$ to the monomer by a few tenths of a kcal $/ \mathrm{mole}$ at most.

From flame photometry measurements, Bulewicz, Phillips, and Sugden ${ }^{41}$ reported $\mathrm{D}_{0}^{\circ} \mathrm{CsI}(\mathrm{g})=$ $83.7 \pm 4 \mathrm{kcal} / \mathrm{mole}$, from which $\Delta \mathrm{H}_{\mathrm{i}, 0}^{\circ} \mathrm{CsI}(\mathrm{g})=-39.4 \mathrm{kcal} / \mathrm{mole}$, or $\Delta \mathrm{H}_{\mathrm{i}, 208}^{\circ} \mathrm{CsI}(\mathrm{g})=-40.3 \pm 4$ $\mathrm{kcal} / \mathrm{mole}$. Thus, $\Delta \mathrm{H}_{\mathrm{r}, 28 \mathrm{~s}}^{\circ} \mathrm{CsI}(\mathrm{s})=-86.7 \pm 4 \mathrm{kcal} / \mathrm{mole}$.

Berkowitz ${ }^{42}$ reported $\mathrm{D}_{0}^{\circ} \mathrm{CsI}(\mathrm{g})=82.3 \pm 1 \mathrm{kcal} / \mathrm{mole}$ from thresholds for photodissociative ionization, from which $\Delta \mathrm{H}_{\mathrm{r}, 298}^{\circ} \mathrm{CsI}(\mathrm{g})=-38.9 \pm 1 \mathrm{kcal} / \mathrm{mole}$ and $\Delta \mathrm{H}_{\mathrm{i}, 298}^{\circ} \mathrm{CsI}(\mathrm{s})=-85.3+1$ $\mathrm{kcal} / \mathrm{mole}$.

Our selected value for the heat of formation of the solid is somewhat more positive than these last two values, but can be regarded as consistent with the assigned uncertainties.

2. Monomer-Dimer Equilibrium in CsI Vapor. Direct experimental evidence for the amount of dimer in CsI vapors is somewhat contradictory. Only the more pertinent references are cited here, including some on other cesium halides and some on theoretical or empirical predictions. It is convenient to refer not only to the percentage of dimer in the vapors, but also to express results or predictions in terms of a dimer dissociation energy (DDE), which is taken as the heat for the reaction $\mathrm{Cs}_{2} \mathrm{I}_{2}(\mathrm{~g})=2 \mathrm{CsI}(\mathrm{g})$. When necessary, thermodynamic functions in Tables IV and $\mathrm{V}$ are used to reduce the DDE to $298.15 \mathrm{~K}$. 
Miller and $\mathrm{Kusch}^{48,44}$ analyzed the velocity distribution of $\mathrm{CsCl}$ and $\mathrm{CsBr}$ molecules through an aperture from an isothermal enclosure (temperature range of $825-1017 \mathrm{~K}$ for $\mathrm{CsCl}$ and $828-965 \mathrm{~K}$ for $\mathrm{CsBr}$ ). They found no substantial evidence for the presence of dimers for those particular halides, but from the experimental uncertainties they placed upper limits of 4 and $6 \%$, respectively, on the percentage of dimer. Rothberg, Eisenstadt, and $\mathrm{Kusch}^{45}$ later applied the same technique to molecules freely evaporating from the surface of single crystals of $\mathrm{CsBr}$ and $\mathrm{CsI}$ and reported $\leq 3 \%$ dimer from $\mathrm{CsBr}(765-830 \mathrm{~K}$ ) and $<0.5 \%$ dimer from CsI $(757-772 \mathrm{~K}$ ) (corresponding to $\mathrm{DDE}_{29 \mathrm{~s}}<32 \mathrm{kcal} / \mathrm{mole}$ ). Akishin and Rambidi ${ }^{40}$ made an electron diffraction study of the structure of the cesium halides and concluded that their results were indirect confirmation of the data of Miller and Kusch, ${ }^{48,44}$ according to which no noticeable amounts of dimer were present in the vapors of the cesium halides.

Other direct experimental data of which we are aware suggest a greater amount of dimer in vapors over the cesium halides. For example, Datz, Smith, and Taylor ${ }^{47}$ found the mole fraction of the dimer over $\mathrm{CsCl}$ to be about 0.2 at $1250 \mathrm{~K}$, decreasing to about 0.1 at $1400 \mathrm{~K}$. They had measured the vapor density as a function of temperature, and their data were used for the JANAF tables. ${ }^{2}$

From mass spectrometric measurements using a double effusion chamber as an ion source, Akishin, Gorokhov, and Sidorov ${ }^{48}$ reported the DDE for CsI to be $31.2 \pm 0.1 \mathrm{kcal} / \mathrm{mole}$ over the temperature range $755-862 \mathrm{~K}$. With this quantity, $\mathrm{DDE}_{298}=32.1 \pm 0.1 \mathrm{kcal} / \mathrm{mole}$. A mass spectrometric study of Knudsen cell effusates over CsI (705-882 K) was also made by Winchell. ${ }^{49}$ From his data, $\mathrm{DDE}_{704}=38 \pm 7 \mathrm{kcal} / \mathrm{mole}$ and therefore $\mathrm{DDE}_{998}=38.9 \pm 7 \mathrm{kcal} / \mathrm{mole}$.

Murgulescu and Topor ${ }^{29,40}$ combined the results of quasi-static Rodebush-Dixon vapor pressure determinations with transpiration measurements to deduce the composition of CsI vapors (1276-1376 K). Over that range they reported the mole fraction of the dimer to be 0.29 . From their equations for the partial pressures of the monomer and dimer, $\mathrm{DDE}_{298}=40.3 \pm 0.3 \mathrm{kcal} / \mathrm{mole}$ (third-law calculation).

Thus, experimentally based values for $\mathrm{DDE}_{298}$ have ranged from 32.1 to $40.3 \mathrm{kcal} / \mathrm{mole}$, if we neglect the even more discordant results of Kusch et al. ${ }^{43-46} \mathrm{~A}$ similar range of values has been proposed from theoretical or empirical considerations. Some of these latter values converted, if necessary, to $\mathrm{DDE}_{298}$ are given in Table VIII. We take $\mathrm{DDE}_{200}$ to be $35 \mathrm{kcal} / \mathrm{mole}$.

3. Heats of Sublimation to the Monomer and to the Dimer. With $D_{D E} E_{29 a}=35 \mathrm{kcal} / \mathrm{mole}$, we calculate heats of sublimation at $298.15 \mathrm{~K}$ to the monomer and dimer from the cited vapor pressure measurements. Results are given in Table IX.

The Knudsen cell data of Refs. 34, 35, and 38 could be corrected for the assumption that the gaseous species was monomeric. However, because of the relatively small amounts of dimer corresponding to the selected DDE and the relatively large disagreement between sets of vapor pressure data, the effect of such a correction would be trivial.

An average of all third-law values of $\Delta \mathrm{H}_{\text {sub1,20s }}$ to the monomer is almost identical with the third-law value in Ref. 32, which in turn has the best agreement between second- and third-law values. Therefore, we take that quantity to be $46.3 \mathrm{kcal} / \mathrm{mole}$, and $\Delta \mathrm{H}_{\mathrm{aubl}, 208}^{\mathrm{g}}$ to the dimer becomes $57.6 \mathrm{kcal} / \mathrm{mole}$. With $\Delta \mathrm{H}_{\text {, }, 298} \mathrm{CsI}(\mathrm{s})=-83.9 \mathrm{kcal} / \mathrm{mole}, \Delta \mathrm{H}_{\mathrm{r}, 298} \mathrm{CsI}(\mathrm{g})=-37.6 \mathrm{kcal} / \mathrm{mole}$, and $\Delta \mathrm{H}_{\mathrm{r}, 20 \mathrm{e}} \mathrm{Cs}_{2} \mathrm{I}_{2}(\mathrm{~g})=-110.2 \mathrm{kcal} / \mathrm{mole}$. Table $\mathrm{X}$ is a tabulation of the pressures calculated with the adopted quantities.

Values of $\Delta \mathrm{H}_{1,208}$ and $\Delta \mathrm{G}_{\mathrm{q}, 208}^{\circ}$ for $\mathrm{CsI}(\mathrm{g})$ are given in Table XI, and Table XII contains the analogous data for $\mathrm{Cs}_{2} \mathrm{I}_{2}(\mathrm{~g})$. 
4. Polyiodides. Thermodynamic data for the polyiodides, such as $\mathrm{CsI}_{8}, \mathrm{CsI}_{4}$, and $\mathrm{Cs}_{2} \mathrm{I}_{8}$, are not included because these condensed phases were not important to the applications considered in this report. For example, the dissociation pressure of $\mathrm{I}_{2}(\mathrm{~g})$ over $\mathrm{CsI}_{3}$ at the melting point $(487 \mathrm{~K})$ is about $0.17 \mathrm{~atm}\left(\mathrm{CsI}_{\mathrm{s}}(\ell)=\mathrm{CsI}(\mathrm{s})+\mathrm{I}_{\mathbf{2}}(\mathrm{g})\right)$. Some relatively recent thermodynamic data for these compounds and references to earlier work can be found in Refs. 54 and 55.

\section{THERMODYNAMIC DATA FOR METHYL IODIDE (CH,I)}

We have calculated ideal gas thermodynamic functions for methyl iodide from $298.15-3000 \mathrm{~K}$ using the harmonic oscillator, rigid rotor approximation. These functions were recently calculated to $1500 \mathrm{~K}$ by Kudchadker and Kudchadker. ${ }^{\text {so }}$ Vibrational frequencies (in $\mathrm{cm}^{-1}$ ) used in Ref. 56 and those used here are given in Table XIII, together with the references used in each tabulation.

In Ref. 56 and in our calculation, the moments of inertia $\left(I_{A}=5.354 \times 10^{-40} \mathrm{~g} \mathrm{~cm}^{2} ; I_{B}=I_{C}=\right.$ $110.92 \times 10^{-40} \mathrm{~g} \mathrm{~cm}^{2}$ ) are calculated from the equilibrium ground-state rotational constants given by Matsuura and Overend, ${ }^{\infty}$ and values for the moments are close to those calculated by Duncan. ${ }^{10}$

Wagman et al." have recently recommended $\Delta \mathrm{H}_{\mathrm{q}, 290}^{\mathrm{n}} \mathrm{CH}_{\mathrm{I}} \mathrm{I}(\mathrm{g})=3.1 \mathrm{kcal} / \mathrm{mole}$. Other recommended values based on evaluations of data from the literature include $3.34 \mathrm{kcal} / \mathrm{mole},{ }^{12} 3.4 \pm$ $0.3 \mathrm{kcal} / \mathrm{mole},{ }^{n}$ and $3.29 \pm 0.28 \mathrm{kcal} / \mathrm{mole} .^{\text {s6 }} \mathrm{We}$ use $3.30 \mathrm{kcal} / \mathrm{mole}$.

Calculated values of $\mathrm{C}_{\mathrm{p}}^{\circ}, \mathrm{S} \&,-\left(\mathrm{F}_{T}-\mathrm{H}_{200}^{\circ}\right) / \mathrm{T}$, and $\mathrm{H}_{q}^{\circ}-\mathrm{H}_{200}^{\circ}$ are given in Table XIV, and values of $\Delta \mathrm{H}^{9}$ and $\Delta \mathrm{G}_{\mathrm{q}}$ are given in Table XV.

\section{THERMODYNAMIC DATA FOR CARBONYL IODIDE (COI $)$}

Molecular parameters have been estimated for gaseous carbonyl iodide and ideal gas thermodynamic functions calculated from 298.15-1500 K. ${ }^{74}$ Although in Ref. 74 the authors also estimated the required $\Delta \mathrm{H}_{\mathrm{q}, 206} \mathrm{COI}_{\mathbf{2}}(\mathrm{g})=-6 \mathrm{kcal} / \mathrm{mole}$, they did not calculate $\Delta \mathrm{G}_{\mathrm{q}}^{\circ}$ as a function of temperature. Estimated molecular parameters for this $\mathrm{C}_{2 v}$ molecule were:

\begin{tabular}{c}
$\begin{array}{c}\text { Frequencies } \\
\left(\mathbf{c m}^{-1}\right)\end{array}$ \\
\hline$v_{1}=1782$ \\
$v_{2}=332$ \\
$v_{3}=134$ \\
$v_{4}=532$ \\
$v_{6}=292$ \\
$v_{6}=439$
\end{tabular}

$$
\begin{gathered}
\begin{array}{c}
\text { Bond Lengths } \\
(\mathrm{A})
\end{array} \\
\hline \mathrm{C}-\mathrm{I}=2.2 \\
\mathrm{C}=\mathrm{O}=1.1 \\
\begin{array}{c}
\text { Bond Angle } \\
\text { (deg) }
\end{array} \\
\hline \mathrm{I}-\mathrm{C}-\mathrm{I}=112
\end{gathered}
$$

We have used their estimates to calculate thermodynamic functions (Table XVI) and $\Delta \mathrm{H}_{\mathrm{i}}^{\circ}$ and $\Delta G_{i}$ (Table XVII) to $3000 \mathrm{~K}$. All necessary auxiliary thermodynamic data are from the JANAF tables. ${ }^{2}$ 


\section{THERMODYNAMIC DATA FOR CESIUM HYDRIDE (CsH)}

Thermodynamic functions to $2000 \mathrm{~K}$ were calculated over $15 \mathrm{yr}$ ago by Kelley, ${ }^{78}$ using spectroscopic constants listed by Herzberg. ${ }^{18}$ Since Herzberg's compilation, spectroscopic constants for CsH have been reported by Bartky, ${ }^{78}$ Ringstrom, ${ }^{77}$ and Tam and Happer. ${ }^{78}$ We use spectroscopic constants for the ${ }^{1} \Sigma^{+}$ground state as listed by Bartky ${ }^{78}$ and calculate thermodynamic functions with a modification of the usual approximation to numerical summation of vibrational-rotational levels given by Mayer and Mayer: ${ }^{24}$

$$
\begin{array}{ll}
\omega_{e}=891.29 \mathrm{~cm}^{-1} & \mathrm{~B}_{\mathrm{e}}=2.7085 \quad \mathrm{~cm}^{-1} \\
\omega_{\mathrm{e}} \mathrm{X}_{\mathrm{e}}=12.794 & \alpha_{\mathrm{e}}=5.70 \times 10^{-2} \\
& \mathrm{D}_{\mathrm{e}}=1.00 \times 10^{-4}
\end{array}
$$

Two other relatively low-lying electronic states are known for $\mathrm{CsH} .{ }^{78,77}$ Because the approximation using the Euler-Maclaurin summation formula ${ }^{24}$ is not satisfactory for excited states of molecules having dissociation energies as low as that of $\mathrm{CsH}$, these states were not included in the calculation. For such states it is preferable to perform a direct summation of vibrationalrotational states and take account of the cut-off of vibrational-rotational quantum numbers as limited by predissociation at the dissociation limit. ${ }^{26,26}$ The simplified procedure used here is considered satisfactory to $3000 \mathrm{~K}$; i.e., if the excited electronic states are ignored, at that temperature the entropy and free-energy function (Table XVIII) are estimated to be low by about 1 and $0.1 \%$, respectively.

The heat of formation of $\mathrm{CsH}(\mathrm{g})$ is based on spectroscopic dissociation energies and is somewhat uncertain. We have used $\Delta \mathrm{H}_{q, 2 m} \mathrm{CsH}(\mathrm{g})=27.8 \mathrm{kcal} / \mathrm{mole}$, which is based on $\mathrm{D}_{0}^{o}=1.81$ $\mathrm{eV}$, as given by Ringstrom. ${ }^{77}$ This is at the lower limit of a range of recommended values to 2.08 $\mathrm{eV},{ }^{70}$ which would correspond to $\Delta \mathrm{H}_{\mathrm{q}, 29 s}^{q}=21.6 \mathrm{kcal} / \mathrm{mole}$. Values for $\Delta \mathrm{H}_{\mathrm{q}}^{\circ}$ and $\Delta \mathrm{G}_{\mathrm{q}}^{\mathrm{q}}$ using the more positive heat of formation at $298.15 \mathrm{~K}$ are given in Table XIX.

We have not derived thermodynamic data for dimeric cesium hydride, although interatomic distances and a dimerization energy have been predicted. ${ }^{79}$

\section{REFERENCES}

1. R. C. Feber, J. L. Lunsford, and W. A. Stark, Jr., "Application of the Complex Equilibrium Code QUIL to Cesium-Impurity Equilibria in the Primary Coolant of High-Temperature GasCooled Reactors," Los Alamos Scientific Laboratory report LA-NUREG-6373 (1976).

2. D. R. Stull et al., JANAF Thermochemical Tables (The Dow Chemical Company, Midland, MI).

3. R. G. Behrens, "The Vapor Pressure of Liquid Cesium by a Knudsen Effusion Radiotracer Technique," submitted to J. Chem. Thermodyn.

4. A. R. Taylor, T. E. Gardner, and D. F. Smith, "Thermodynamic Properties of Cesium Chloride and Cesium Iodide from $0^{\circ}$ to $300^{\circ} \mathrm{K}$," U.S. Bur. Mines report RI 6157 (1963).

5. M. Sorai, H. Suga, and S. Seki, "Thermal Properties of Alkali Halide Crystals with the CsCltype Structure. I. Construction of a Calorimeter for the Temperature Region $1^{\circ}-20^{\circ} \mathrm{K}$ and Heat 
Capacities of Caesium Bromide and Caesium Iodide between $1.5^{\circ}$ and $300^{\circ} \mathrm{K}$, "Bull. Chem. Soc. Japan 41, 312-321 (1968).

6. B. J. Marshall and J. R. Kunkel, "Heat Capacity and Elastic Constants of CsI at Low Temperatures," J. Appl. Phys. 40, 5191-5192 (1969).

7. D. F. Smith et al., "Construction, Calibration, and Operation of Ice Calorimeters," U.S. Bur. Mines report RI 5832 (1961).

8. C. E. Kaylor, G. E. Walden, and D. F. Smith, "High Temperature Heat Content and Entropies of Cesium Chloride and Cesium Iodide," J. Phys. Chem. 64, 276-278 (1960).

9. F. D. Rossini et al., "Selected Values of Chemical Thermodynamic Properties," Nat. Bur. Stand. Circ. 500 (1952).

10. V. I. Minchenko, M. V. Smirnov, and V. P. Stepanov, "Isothermal Compressibility and Specific Heat at a Constant Volume of Fused Metal Halides," Zh. Fiz. Khim. 49, 1320-1321 (1975).

11. A. S. Dworkin and M. A. Bredig, "The Heat of Fusion of the Alkali Metal Halides," J. Phys. Chem. 64, 269-272 (1960).

12. J. Bousquet, G. Perachon, and J. Remy, "Mesures calorimetriques des chaleurs de fusion des iodures de sodium, potassium, rubidium et caesium," Bull Soc. chim. France 1967 (1), 238-239.

13. G. N. Lewis et al., Thermodynamics, 2nd Edition (McGraw-Hill Book Co., New York, 1961), p. 678.

14. L. Brewer and E. Brackett, "The Dissociation Energies of Gaseous Alkali Halides," Chem. Rev. 61, 425-432 (1961).

15. A. F. Borob'ev, N. A. Ibragim, and S. M. Skuratov, "Enthalpy of Formation of Certain Rubidium and Caesium Salts," Russ. J. Inorg. Chem. 11, 13-15 (1966).

16. G. B. Naumov, B. N. Ryzhenko, and I. L. Khodakovsky, "Handbook of Thermodynamic Data," U.S. Dep. Commer., National Technical Information Service report PB-226 722 (January 1974) (a translation of a Russian report issued in 1971).

17. V. B. Parker, "Thermal Properties of Aqueous Uni-univalent Electrolytes," Nat. Bur. Stand., National Standard Reference Data Series report NSRDS-NBS 2 (April 1965).

18. G. Herzberg, Molecular Spectra and Molecular Structure. I. Spectra of Diatomic Molecules, 2nd Edition (D. Van Nostrand Co., Toronto, 1950).

19. R. F. Barrow and A. D. Caunt, "The Ultra-violet Absorption Spectra of Some Gaseous Alkali-metal Halides and the Dissociation Energy of Fluorine," Proc. Roy. Soc. London A219, 120-140 (1953).

20. A. Honig et al., "Microwave Spectra of the Alkali Halides," Phys. Rev. 96, 629-642 (1954). 
21. S. A. Rice and W. Klemperer, "Spectra of the Alkali Halides. II. The Infrared Spectra of the Sodium and Potassium Halides, $\mathrm{RbCl}$ and $\mathrm{CsCl}$," J. Chem. Phys. 27, 573-579 (1957).

22. J. R. Rusk and W. Gordy, "Millimeter Wave Molecular Beam Spectroscopy: Alkali Bromides and Iodides," Phys. Rev. 127, 817-830 (1962).

23. R. Honerjäger and R. Tischer, "Mikrowellenrotationsspecktren der Molekeln CsF, CsCl, CsBr und CsI," Z. Naturforsch. 29a, 819-821 (1974).

24. J. E. Mayer and M. G. Mayer, Statistical Mechanics (John Wiley \& Sons, New York, 1940).

25. R. C. Feber and C. C. Herrick, "An Improved Calculation of the Ideal Gas Thermodynamic Functions of Selected Diatomic Molecules," Los Alamos Scientific Laboratory report LA-3597 (1967).

26. S. I. Gorbov et al., "Calculation of Thermodynamic Functions of Ideal Diatomic Gases by the Method of Direct Summation," Teplofiz. Vys. Temp. 13, 503-510 (1975).

27. K. S. Krasnov, V. G. Solomonik, and E. V. Morozov, "Thermodynamic Functions and the Molecular Parameters of Rhombic Dimer Molecules of Alkali Metal Halides," Teplofiz. Vys. Temp. (Engl. Transl.) 10, 682-686 (1972).

28. J. Berkowitz, "Molecular Structure and Vibrational Spectra of Alkali Halide Dimers," J. Chem. Phys. 29, 1386-1394 (1958).

29. J. Berkowitz, "Vibrational Frequencies of Alkali Halide Dimers. II. Bending, Symmetric Stretch, and B $1 \mathrm{~g}$ Modes," J. Chem. Phys. 32, 1519-1522 (1960).

30. S. H. Bauer, R. M. Diner, and R. F. Porter, "Entropies and Energies of Dimerization of Alkali Metal Halides," J. Chem. Phys. 29, 991-995 (1958).

31. O. Ruff and S. Mugdan, "Die Messung von Dampfdrucken bie hohen Temperaturen und die Dampfdrucke der Alkalihalogenide," Z. Anorg. Allg. Chem. 117, 147-171 (1921).

32. H. von Wartenberg and H. Schulz, "Der Dampfdruck einiger Salze. II." Z. Elektrochem. 27, 568-573 (1921).

33. V. Deitz, "The Vapor Pressure of Potassium Chloride and Caesium Iodide Crystals," J. Chem. Phys. 4, 575-580 (1936).

34. G. E. Cogin and G. E. Kimball, "The Vapor Pressure of Some Alkali Halides," J. Chem. Phys. 16, 1035-1048 (1948).

35. M. D. Scheer and J. Fine, "Entropies, Heats of Sublimation, and Dissociation Energies of the Cesium Halides," J. Chem. Phys. 36, 1647-1653 (1962).

36. I. G. Murgulescu and L. Topor, "Thermodynamical Data of Molten Rubidium and Caesium Halides from Vapour Pressure Determinations," Rev. Roum. Chim. 12, 1077-1083 (1967). 
37. C. T. Ewing and K. H. Stern, "Equilibrium Vaporization Rates and Vapor Pressures of Solid and Liquid Sodium Chloride, Potassium Chloride, Potassium Bromide, Cesium Iodide, and Lithium Fluoride," J. Phys. Chem. 78, 1998-2005 (1974).

38. L. L. Makarov and D. Yu. Stupin, "Partial Pressures over the Solid Solutions Rubidium Bromide-Caesium Bromide and Rubidium Iodide-Caesium Iodide in the Temperature Range 650-850K," Russ. J. Phys. Chem. 42, 786-788 (1968).

39. I. G. Murgulescu and L. Topor, "L'association moleculaire des iodures alcalins en phase gazeuse," Rev. Roum. Chim. 15, 997-1004 (1970).

40. L. Topor, "Thermodynamic Study of Alkali Halide Vapors in Equilibrium with the Liquid Phase," J. Chem. Thermodyn. 4, 739-744 (1972).

41. E. M. Bulewicz, L. F. Phillips, and T. M. Sugden, "Determination of Dissociation Constants and Heats of Formation of Simple Molecules by Flame Photometry. Part 8. Stabilities of the Gaseous Diatomic Halides of Certain Metals," Trans. Faraday Soc. 57, 921-931 (1961).

42. J. Berkowitz, "Photoionization of High-Temperature Vapors. V. Cesium Halides; Chemical Shift of Autoionization," J. Chem. Phys. 50, 3503-3512 (1969).

43. R. C. Miller and P. Kusch, "Molecular Composition of Alkali Halide Vapors," J. Chem. Phys. 25, 860-876 (1956).

44. R. C. Miller and P. Kusch, "Errata: Molecular Composition of Alkali Halide Vapors," J. Chem. Phys. 27, 981 (1957).

45. G. M. Rothberg, M. Eisenstadt, and P.Kusch, "Free Evaporation of Alkali Halide Crystals," J. Chem. Phys. 30, 517-527 (1959).

46. P. A. Akishin and N. G. Rambidi, "Electron-Diffraction Investigations of the Structure of Molecules of Cesium Halides," Russ. J. Inorg. Chem. 3, 9-13 (1958).

47. S. Datz, W. T. Smith, and E. H. Taylor, "Molecular Association in Alkali Halide Vapors," J. Chem. Phys. 34, 558-564 (1961).

48. P. A. Akishin, L. N. Gorokhov, and L. N. Sidorov, "A Mass-Spectrometric Study of Cesium Halides," Proc. Acad. Sci. USSR (Phys. Chem. Sec., Engl. Transl.) 1960, 1001-1004.

49. P. Winchell, "Mass Spectrometric Investigation of Barium Iodide and Caesium Iodide Vaporizations," Nature 206, 1252 (1965).

50. O. G. Polyachenok, "Dimerization of Gaseous Metal Halides," Russ. J. Phys. Chem. 44, 1371 (1970).

51. T. A. Milne and D. Cubicciotti, "Calculation of the Energies of Gaseous Alkali Halide Dimer Molecules," J. Chem. Phys. 29, 846-851 (1958).

52. T. A. Milne and D. Cubicciotti, "Calculation of the Energies of Some Alkali Halide Trimers," J. Chem. Phys. 30, 1625-1626 (1959). 
53. M. Blander, "Association of Vapors of Ionic Salts. A Dimensional Theory," J. Chem. Phys. 41, 170-176 (1964).

54. L. E. Topol, "Thermodynamic Studies in the Polyiodide Systems RbI-RbI, $\mathrm{NH}_{4} \mathrm{I}_{-} \mathrm{NH}_{4} \mathrm{I}_{3}$, CsI-CsI $I_{s}$, and CsI -CsI $_{4}, "$ Inorg. Chem. 7, 451-454 (1968).

55. A. V. Babkov and B. D. Stepin, "Dissociation Pressure of Potassium, Rubidium, and Caesium Polyiodoiodates," Russ. J. Inorg. Chem. 13, 5-7 (1968).

56. S. A. Kudchadker and A. P. Kudchadker, "Ideal Gas Thermodynamic Properties of the Eight Bromo- and Iodomethanes," J. Phys. Chem. Ref. Data 4, 457-470 (1975).

57. T. Shimanouchi, "Tables of Molecular Vibrational Frequencies. Consolidated Volume 1," Nat. Bur. Stand., National Reference Data series report NSRDS-NBS 39 (1972).

58. W. T. King, I. M. Mills, and B. Crawford, "Normal Coordinates in the Methyl Halides," J. Chem. Phys. 27, 455-457 (1957).

59. E. W. Jones and H. W. Thompson, "Vibration-Rotation Bands and Molecular Constants of Methyl Iodide," Proc. Roy. Soc. London 288A, 50-59 (1965).

60. Y. Morino and J. Nakamura, "Vibration-Rotation Spectra, the Coriolis Coupling Constants and the Intramolecular Force Field of Symmetric Top Molecules. I. The E-Type Fundamental Bands of Methyl and Methyl-d, Halides," Bull. Chem. Soc. Japan 38, 443-459 (1965).

61. Y. Morino, J. Nakamura, and S. Yamamoto, "Fermi Resonances in the Rotational Structure of the Infrared Spectra of Methyl Iodide," J. Mol. Spectrosc. 22, 34-48 (1967).

62. T. L. Barnett and T. H. Edwards, "Determination of $A_{o}$ for Axially Symmetric Molecules. Part III. $\mathrm{CH}_{3} \mathrm{I}$," J. Mol. Spectrosc. 23, 302-306 (1967).

63. R. J. L. Popplewell and H. W. Thompson, "The Vibrational-Rotation Band $v_{1}$ of Methyl Iodide," Spectrochim. Acta 25A, 287 (1969).

64. P. Connes et al., "Etude de la Bande $v_{4}$ de L'lodure de Methyle $\mathrm{ICH}_{\mathbf{s}}, "$ J. Phys. (Paris) 33, 77. 84 (1972).

65. H. Matsuura, T. Nakagawa, and J. Overend, "Detailed Analysis of $v_{5}$ of $\mathrm{CH}_{8} \mathrm{I}$ : Fermi and Coriolis Resonances with $v_{3}+v_{6}$ and $v_{2}, "$ J. Chem. Phys. 59, 1449-1456 (1973).

66. H. Matsuura, Y. Kawashima, and C. Hirose, "Combined Analysis of Microwave and Infrared Spectra of Methyl Iodide: Rotational and $\ell$-Type Doubling Constants of the $v_{b}, v_{3}+v_{6}$ and $v_{2}$ States," J. Mol. Struct. 20, 205-212 (1974).

67. A. G. Maki and R. M. Hexter, "Resonance Interactions with $v_{5}$ of $\mathrm{CH}_{3} \mathbf{I}$; A Method of Determining $A_{\circ}, "$ J. Chem. Phys. 53, 453-454 (1970).

68. H. Matsuura and J. Overend, "Infrared Spectra of $\mathrm{CH}_{3} \mathrm{I}$. The $v_{6}$ and $v_{2}+v_{6}$ Bands at High Resolution," Spectrochim. Acta 27A, 2165-2171 (1971). 
69. H. Matsuura and J. Overend, "Equilibrium Structure of Methyl Iodide," J. Chem. Phys. 56, 5725-5727 (1972).

70. J. L. Duncan, "The Equilibrium Geometries of the Methyl Halides," J. Mol. Struct. 6, 447456 (1970).

71. D. D. Wagman et al., "Selected Values of Chemical Thermodynamic Properties," Nat. Bur. Stand. report NBS-TN-270-3 (1968).

72. D. R. Stull, E. F. Westrum, and G. C. Sinke, The Chemical Thermodynamics of Organic Compounds (John Wiley and Sons, New York, 1969).

73. J. D. Cox and G. Pilcher, Thermochemistry of Organic and Organometallic Compounds (Academic Press, London and New York, 1970).

74. R. G. Behrens and S. Aronson, "HTGR Safety Evaluation Division. Quarterly Report, April 1, 1975 - June 30, 1975," D. G. Schweitzer, Ed., Brookhaven National Laboratory report BNL 50460 (1975).

75. K. K. Kelley, "Contributions to the Data on Theoretical Metallurgy. XIII. HighTemperature Heat-Content, Heat-Capacity, and Entropy Data for the Elements and Inorganic Compounds," U.S. Bur. Mines Bull. 584 (1960).

76. I. R. Bartky, "The Absorption Spectrum of Cesium Deuteride. The A ' $\Sigma$ State of CsH," J. Mol. Spectrosc. 21, 25-28 (1966).

77. U. Ringstrom, "New Band System and Klein-Rydberg Potential Curves of Cesium Hydride," J. Mol. Spectrosc. 36, 232-247 (1970).

78. A. C. Tam and W. Happer, "Spectroscopy of the $\mathrm{CsH}\left(\mathrm{X}^{1} \Sigma^{+}\right)$State by Laser-Excited Fluorescence," J. Chem. Phys. 64, 2456-2459 (1976).

79. A. Companion, J. R. Tyndall, and A. Studencki, "A Rittner Ionic Model of Alkali Hydride Dimers," J. Phys. Chem. 75, 984-985 (1971).

TABLE I

THERMOIYYNAMIC QUANTITIES CALCULATED FOR

THE CESIUM-IOININE SYSTEM AT $298.15 \mathrm{~K}$

\begin{tabular}{|c|c|c|c|}
\hline & $\begin{array}{c}C_{\mathrm{p}, 2 \mathrm{~mm}}^{\mathrm{g}} \\
\text { (Gibbs/mole) }\end{array}$ & $\begin{array}{c}\mathbf{S}_{200}^{\mathbf{v}} \\
\text { (gibbs/mole) } \\
\end{array}$ & $\begin{array}{l}H_{\mathrm{smo}}^{\mathrm{o}}-\mathrm{H}_{\mathrm{o}}^{\mathrm{o}} \\
(\mathrm{cal} / \mathrm{mole})\end{array}$ \\
\hline Ref. 4 & 12.62 & 29.41 & 3231.95 \\
\hline Ref. 5 & 12,571 & 29.127 & 3216.44 \\
\hline Recalculation & 12.566 & 29.108 & 3216.36 \\
\hline $\begin{array}{l}\text { Recalculation of } \\
\text { Refs. } 5 \text { and } 6\end{array}$ & 12.566 & 29.117 & 3216.43 \\
\hline $\begin{array}{l}\text { Recalculation of } \\
\text { all data }\end{array}$ & 12.591 & 29.192 & 3221.31 \\
\hline
\end{tabular}


TABLE II

HIGH-TEMPERATURE THERMODYNAMIC FUNCTIONS FOR CESIUM IODIDE $(s, \ell)$

\begin{tabular}{|c|c|c|c|c|}
\hline $\begin{array}{l}\text { Temp. } \\
\text { (K) }\end{array}$ & $\begin{array}{c}\mathrm{C}_{p}^{o} \\
\text { (gibbs/mole) }\end{array}$ & $\begin{array}{c}\mathbf{S}_{\mathrm{T}}^{\mathbf{o}} \\
\text { (gibbs/mole) }\end{array}$ & $\begin{array}{c}-\left(\mathrm{F}_{\mathrm{T}}^{\mathrm{o}}-\mathrm{H}_{2 \mathrm{os}}^{\mathrm{o}}\right) / \mathrm{T} \\
\text { (gibbs/mole) }\end{array}$ & $\begin{array}{c}\mathbf{H}_{\mathbf{T}}^{\mathrm{o}}-\mathrm{H}_{\mathbf{2 g s}}^{\mathrm{o}} \\
\text { (kcal/mole) }\end{array}$ \\
\hline $298.15(\mathrm{~s})$ & 12.590 & 29.200 & 29.200 & 0.000 \\
\hline 300.00 & 12.595 & 29.278 & 29.200 & 0.023 \\
\hline 325.00 & 12.675 & 30.287 & 29.245 & 0.339 \\
\hline 350.00 & 12.750 & 31.231 & 29.354 & 0.657 \\
\hline 375.00 & 12.830 & 32.114 & 29.509 & 0.977 \\
\hline 400.00 & 12.915 & 32.942 & 29.698 & 1.298 \\
\hline 425.00 & 13.010 & 33.730 & 29.912 & 1.623 \\
\hline 450.00 & 13.120 & 34.477 & 30.145 & 1.949 \\
\hline 475.00 & 13.235 & 35.187 & 30.391 & 2.278 \\
\hline 500.00 & 13.367 & 35.871 & 30.649 & 2.611 \\
\hline 550.00 & 13.671 & 37.159 & 31.183 & 3.287 \\
\hline 600.00 & 13.975 & 38.360 & 31.731 & 3.978 \\
\hline 700.00 & 14.583 & 40.563 & 32.840 & 5.406 \\
\hline 800.00 & 15.191 & 42.549 & 33.931 & 6.895 \\
\hline 899.00 & 15.793 & 44.354 & 34.980 & 8.428 \\
\hline $899.00(l)$ & 16.450 & 50.973 & 34.980 & 14.378 \\
\hline 900.00 & 16.450 & 50.991 & 34.997 & 14.394 \\
\hline 1000.00 & 16.450 & 52.724 & 36.685 & 16.039 \\
\hline 1100.00 & 16.450 & 54.292 & 38.215 & 17.684 \\
\hline 1200.00 & 16.450 & 55.723 & 39.616 & 19.329 \\
\hline 1300.00 & 16.450 & 57.040 & 40.906 & 20.974 \\
\hline 1400.00 & 16.450 & 58.259 & 42.103 & 22.619 \\
\hline 1500.00 & 16.450 & 59.394 & 43.218 & 24.264 \\
\hline 1600.00 & 16.450 & 60.456 & 44.263 & 25.909 \\
\hline 1700.00 & 16.450 & 61.453 & 45.245 & 27.554 \\
\hline 1800.00 & 16.450 & 62.393 & 46.172 & 29.199 \\
\hline 1900.00 & 16.450 & 63.283 & 47.049 & 30.844 \\
\hline 2000.00 & 16.450 & 64.127 & 47.882 & 32.489 \\
\hline 2100.00 & 16.450 & 64.929 & 48.675 & 34.134 \\
\hline 2200.00 & 16.450 & 65.694 & 49.431 & 35.779 \\
\hline 2300.00 & 16.450 & 66.426 & 50.154 & 37.424 \\
\hline 2400.00 & 16.450 & 67.126 & 50.847 & 39.069 \\
\hline 2500.00 & 16.450 & 67.797 & 51.512 & 40.714 \\
\hline 2600.00 & 16.450 & 68.442 & 52.150 & 42.359 \\
\hline 2700.00 & 16.450 & 69.063 & 52.765 & 44.004 \\
\hline 2800.00 & 16.450 & 69.662 & 53.358 & 45.649 \\
\hline 2900.00 & 16.450 & 70.239 & 53.930 & 47.294 \\
\hline 3000.00 & 16.450 & 70.796 & 54.483 & 48.939 \\
\hline
\end{tabular}

$\mathrm{H}_{290}-\mathrm{H}_{0}^{\circ}=3.221 \mathrm{kcal} / \mathrm{mole}$ 
TABLE III

THERMODYNAMICS OF FORMATION OF CESIUM IODIDE $(s, \ell)$

\begin{tabular}{|c|c|c|}
\hline $\begin{array}{l}\text { Temp. } \\
\text { (K) }\end{array}$ & $\begin{array}{c}\Delta \mathbf{H}_{\mathbf{f}}^{\mathbf{P}} \\
\text { (kcal/mole) }\end{array}$ & $\begin{array}{c}\Delta G_{p}^{o} \\
\text { (kcal/mole) }\end{array}$ \\
\hline $298.15(\mathrm{~s})$ & -83.900 & -82.400 \\
\hline 300.00 & -83.903 & -82.391 \\
\hline 400.00 & -86.476 & -81.633 \\
\hline 500.00 & -91.673 & -79.930 \\
\hline 600.00 & -91.497 & -77.596 \\
\hline 700.00 & -91.258 & -75.298 \\
\hline 800.00 & -80.960 & -73.038 \\
\hline 899.00 & -90.606 & -70.841 \\
\hline $899.00(l)$ & -84.657 & -70.841 \\
\hline 900.00 & -84.652 & -70.823 \\
\hline 1000.00 & -100.280 & -68.490 \\
\hline 1100.00 & -99.585 & -65.345 \\
\hline 1200.00 & -98.891 & -62.263 \\
\hline 1300.00 & -98.198 & -59.238 \\
\hline 1400.00 & -97.507 & -56.269 \\
\hline 1500.00 & -96.815 & -53.347 \\
\hline 1600.00 & -96.126 & -50.472 \\
\hline 1700.00 & -95.439 & -47.639 \\
\hline 1800.00 & -94.755 & -44.848 \\
\hline 1900.00 & -94.073 & -42.092 \\
\hline 2000.00 & -93.396 & -39.375 \\
\hline 2100.00 & -92.725 & -36.689 \\
\hline 2200.00 & -92.061 & -34.037 \\
\hline 2300.00 & -91.402 & -31.413 \\
\hline 2400.00 & -90.754 & -28.820 \\
\hline 2500.00 & -90.117 & -26.254 \\
\hline 2600.00 & -89.490 & -23.710 \\
\hline 2700.00 & -88.878 & -21.190 \\
\hline 2800.00 & -88.282 & -18.695 \\
\hline 2900.00 & -87.702 & -16.220 \\
\hline 3000.00 & -87.142 & -13.766 \\
\hline
\end{tabular}


TABLE IV

IDEAL GAS THERMODYNAMIC FUNCTIONS OF MONOMERIC CESIUM IODIDE (g)

\begin{tabular}{|c|c|c|c|c|}
\hline $\begin{array}{c}\text { Temp. } \\
(\mathbf{K})\end{array}$ & $\begin{array}{c}\mathrm{C}_{\mathrm{p}}^{\mathrm{o}} \\
\text { (gibbs/mole) } \\
\end{array}$ & $\begin{array}{c}\mathbf{S}_{\mathrm{T}}^{o} \\
\text { (gibbs/mole) } \\
\end{array}$ & $\begin{array}{c}-\left(\mathrm{F}_{\mathrm{T}}^{\mathrm{o}}-\mathrm{H}_{298}^{\circ}\right) / \mathrm{T} \\
(\text { gibbs/mole })\end{array}$ & $\begin{array}{c}\mathbf{H}_{\mathbf{T}}-\mathbf{H}_{298}^{\mathrm{o}} \\
\text { (kcal/mole) }\end{array}$ \\
\hline 0.00 & 0.000 & 0.000 & Infinite & -2.521 \\
\hline 100.00 & 8.540 & 56.157 & 73.656 & -1.750 \\
\hline 200.00 & 8.866 & 62.208 & 66.583 & -0.875 \\
\hline 298.15 & 8.951 & 65.767 & 65.767 & 0.000 \\
\hline 300.00 & 8.952 & 65.822 & 65.767 & 0.017 \\
\hline 400.00 & 8.998 & 68.404 & 66.119 & 0.914 \\
\hline 500.00 & 9.031 & 70.416 & 66.784 & 1.816 \\
\hline 600.00 & 9.061 & 72.065 & 67.531 & 2.720 \\
\hline 700.00 & 9.089 & 73.464 & 68.281 & 3.628 \\
\hline 800.00 & 9.116 & 74.679 & 69.007 & 4.538 \\
\hline 900.00 & 9.143 & 75.755 & 69.698 & 5.451 \\
\hline 1000.00 & 9.170 & 76.719 & 70.353 & 6.367 \\
\hline 1100.00 & 9.198 & 77.595 & 70.972 & 7.285 \\
\hline 1200.00 & 9.226 & 78.396 & 71.558 & 8.206 \\
\hline 1300.00 & 9.254 & 79.136 & 72.112 & 9.130 \\
\hline 1400.00 & 9.283 & 79.823 & 72.639 & 10.057 \\
\hline 1500.00 & 9.313 & 80.464 & 73.139 & 10.987 \\
\hline 1600.00 & 9.343 & 81.066 & 73.616 & 11.920 \\
\hline 1700.00 & 9.374 & 81.633 & 74.071 & 12.856 \\
\hline 1800.00 & 9.405 & 82.170 & 74.507 & 13.795 \\
\hline 1900.00 & 9.437 & 82.680 & 74.923 & 14.737 \\
\hline 2000.00 & 9.470 & 83.164 & 75.323 & 15.682 \\
\hline 2100.00 & 9.503 & 83.627 & 75.708 & 16.631 \\
\hline 2200.00 & 9.537 & 84.070 & 76.078 & 17.583 \\
\hline 2300.00 & 9.571 & 84.495 & 76.435 & 18.538 \\
\hline 2400.00 & 9.606 & 84.903 & 76.779 & 19.497 \\
\hline 2500.00 & 9.642 & 85.296 & 77.112 & 20.459 \\
\hline 2600.00 & 9.679 & 85.675 & 77.434 & 21.426 \\
\hline 2700.00 & 9.715 & 86.041 & 77.746 & 22.395 \\
\hline 2800.00 & 9.753 & 86.395 & 78.049 & 23.369 \\
\hline 2900.00 & 9.791 & 86.738 & 78.342 & 24.346 \\
\hline 3000.00 & 9.830 & 87.070 & 78.628 & 25.327 \\
\hline
\end{tabular}


TABLE V

IDEAL GAS THERMODYNAMIC FUNCTIONS OF DIMERIC CESIUM IODIDE (g)

\begin{tabular}{|c|c|c|c|c|}
\hline $\begin{array}{c}\text { Temp. } \\
\text { (K) }\end{array}$ & $\begin{array}{c}\mathrm{Co}_{\mathrm{p}}^{\circ} \\
\text { (gibbs/mole) }\end{array}$ & $\begin{array}{c}\mathbf{S}_{\mathrm{T}}^{\circ} \\
\text { (gibbs/mole) }\end{array}$ & $\begin{array}{c}-\left(F_{\mathrm{T}}^{\mathrm{o}}-\mathrm{H}_{204}^{\mathrm{o}}\right) / \mathrm{T} \\
(\mathrm{gibbs} / \mathrm{mole})\end{array}$ & $\begin{array}{l}\mathbf{H}_{\mathbf{q}}-\mathrm{H}_{\mathbf{2 0}}^{\mathrm{e}} \\
(\mathrm{kcal} / \mathrm{mole})\end{array}$ \\
\hline 0.00 & 0.000 & 0.000 & Infinite & -5.400 \\
\hline 100.00 & 19.001 & 81.207 & 119.987 & -3.878 \\
\hline 200.00 & 19.645 & 94.647 & 104.325 & -1.935 \\
\hline 298.15 & 19.769 & 102.519 & 102.519 & 0.000 \\
\hline 300.00 & 19.778 & 102.642 & 102.520 & 0.037 \\
\hline 400.00 & 19.814 & 108.336 & 103.296 & 2.016 \\
\hline 500.00 & 19.835 & 112.760 & 104.763 & 3.999 \\
\hline 600.00 & 19.846 & 116.377 & 106.406 & 5.983 \\
\hline 700.00 & 19.853 & 119.437 & 108.055 & 7.968 \\
\hline 800.00 & 19.857 & 122.089 & 109.647 & 9.953 \\
\hline 900.00 & 19.860 & 124.428 & 111.162 & 11.939 \\
\hline 1000.00 & 19.862 & 126.520 & 112.595 & 13.925 \\
\hline 1100.00 & 19.864 & 128.413 & 113.948 & 15.912 \\
\hline 1200.00 & 19.865 & 130.142 & 115.227 & 17.898 \\
\hline 1300.00 & 19.866 & 131.732 & 116.436 & 19.885 \\
\hline 1400.00 & 19.867 & 133.204 & 117.582 & 21.871 \\
\hline 1500.00 & 19.868 & 134.575 & 118.669 & 23.858 \\
\hline 1600.00 & 19.868 & 135.857 & 119.704 & 25.845 \\
\hline 1700.00 & 19.868 & 137.062 & 120.690 & 27.832 \\
\hline 1800.00 & 19.869 & 138.197 & 121.631 & 29.819 \\
\hline 1900.00 & 19.869 & 139.272 & 122.532 & 31.805 \\
\hline 2000.00 & 19.869 & 140.291 & 123.395 & 33.792 \\
\hline 2100.00 & 19.870 & 141.260 & 124.222 & 35.779 \\
\hline 2200.00 & 19.870 & 142.184 & 125.018 & 37.766 \\
\hline 2300.00 & 19.870 & 143.068 & 125.784 & 39.753 \\
\hline 2400.00 & 19.870 & 143.913 & 126.522 & 41.740 \\
\hline 2500.00 & 19.870 & 144.725 & 127.234 & 43.727 \\
\hline 2600.00 & 19.870 & 145.504 & 127.921 & 45.714 \\
\hline 2700.00 & 19.870 & 146.254 & 128.587 & 47.701 \\
\hline 2800.00 & 19.870 & 146.976 & 129.231 & 49.688 \\
\hline 2900.00 & 19.871 & 147.674 & 129.855 & 51.675 \\
\hline 3000.00 & 19.871 & 148.347 & 130.460 & 53.662 \\
\hline
\end{tabular}

TABLE VI

VAPOR PRESSURE DATA FOR CESIUM IODIDE

\begin{tabular}{|c|c|c|c|}
\hline Ref. & Method & Temp. Range (K) & No. Points \\
\hline 31 & Boiling point & $1325-1553$ & 9 \\
\hline 32 & Boiling point & $1296-1553$ & 5 \\
\hline 33 & Absolute manometer & $767-847$ & 15 \\
\hline 34 & Knudsen cell & $696-894$ & 51 \\
\hline 35 & Knudsen cell & $671-876$ & 22 \\
\hline 36 & Quasi-static ${ }^{b}$ & $1156-1374$ & 12 \\
\hline 37 & Knudsen cell & c & c \\
\hline 38 & Knudsen cell & 650.850 & $\mathrm{~d}$ \\
\hline
\end{tabular}

- Force exerted by beam of Cal(g) on aluminum vane attached to quartz fiber (electromagnetic balance).

-Rodebush-Dixon method: additional data given as equations in Refs. 39 and 40 Temperature range unstated, but apparently above and below the melting point: vapor pressures not given, but stated to be $20 \%$ below those of Ref. 35 .

${ }^{\circ}$ Dat a represented by equation. 
TABLE VII

CALCULATED HEATS OF SUBLIMATION FOR CESIUM IODIDE AT 298.15 K

\begin{tabular}{|c|c|c|}
\hline \multirow[b]{2}{*}{ Ret. } & \multicolumn{2}{|c|}{ 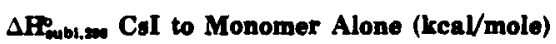 } \\
\hline & Third Lev & Second Law \\
\hline $\begin{array}{l}31 \\
32 \\
33 \\
34\end{array}$ & $\begin{array}{l}46.683 \pm 0.632 \\
46.248 \pm 0.190 \\
46.958 \pm 0.062 \\
46.602 \pm 0.655\end{array}$ & $\begin{array}{l}59.547 \\
48.518 \\
48.235 \\
49.251\end{array}$ \\
\hline & $\begin{array}{l}(47.215 \pm 0.165 \\
(46.012 \pm 0.322\end{array}$ & $\begin{array}{l}48.949)^{\star} \\
49.107)^{\curvearrowleft}\end{array}$ \\
\hline 35 & $45.961 \pm 0.193$ & 48.042 \\
\hline 36 & $46.158 \pm 0.048$ & 46.908 \\
\hline 38 & 44.965 & 46.974 \\
\hline
\end{tabular}

-Apparently, data were not reproducible and depended on the experimental sequence for some unspecified reacon. The data can be broken into two parts, and calculated heats from the two subsets are enclowed in parntheses.

TABLE VIII

DDE m VALUES CALCULATED FROM THEORETICAL OR EMPIRICAL PREDICTIONS

DDEm

(kcal/molo)

35

31.5

32

$\frac{\text { Reference }}{\text { Polyachenok }}$
Brewer and Brackett ${ }^{30}$
Milne and Cubicciotti"

Blander"

Datz et al."

Bauer et al. ${ }^{20}$
Source of Calculation

From an electrostatic model

From the authors' estimate of $\mathrm{DDE}_{1000}=32 \mathrm{kcal} / \mathrm{mole}$

Based on the authors' calculation of monomer and dimer energies, which in turn was based on a model suggested by Pauling. The authors have also calculated energies of the gaseous trimers ${ }^{32}$

From a dimensional analysis of the statistical-mechanical equations for the association of ionic molecules in the vapor

An extrapolation of the authors' plot of the DDE's of the alkali halide dimers vs the reciprocal of the anion-cation distance in the dimers

An extrapolation of a graphical correlation similar to that in Ref. 47. 
TABLE IX

HEATS OF SUBLIMATION FOR CESIUM IODIDE AT $298.15 \mathrm{~K}$ WITH DDE $_{298}=35 \mathrm{kcal} / \mathrm{mole}$

\begin{tabular}{|c|c|c|c|c|}
\hline \multirow[b]{3}{*}{ Ref. } & \multicolumn{4}{|c|}{$\Delta H_{\text {subl,298 }}^{\text {o }}$ (kcal/mole) } \\
\hline & \multicolumn{2}{|c|}{ To Monomer } & \multicolumn{2}{|c|}{ To Dimer } \\
\hline & Third Law & Second Law & Third Law & Second Law \\
\hline 31 & $46.855 \pm 0.593$ & 58.793 & $58.710 \pm 1.186$ & 82.587 \\
\hline 32 & $46.463 \pm 0.167$ & 48.400 & $57.872 \pm 0.335$ & 61.799 \\
\hline 33 & $46.986 \pm 0.058$ & 48.046 & $58.972 \pm 0.116$ & 61.093 \\
\hline \multirow[t]{3}{*}{34} & $46.641 \pm 0.631$ & 49.229 & $58.282 \pm 1.263$ & 63.458 \\
\hline & $(47.239 \pm 0.158$ & 48.784 & $59.478 \pm 0.316$ & $62.567)^{a}$ \\
\hline & $(45.066 \pm 0.288$ & 48.875 & $57.131 \pm 0.577$ & $62.751)^{a}$ \\
\hline 35 & $45.994 \pm 0.171$ & 47.752 & $56.987 \pm 0.341$ & 60.505 \\
\hline 36 & $46.325 \pm 0.035$ & 46.793 & $57.650 \pm 0.070$ & 58.586 \\
\hline 38 & 45.029 & 46.589 & 55.058 & 58.177 \\
\hline
\end{tabular}

See footnote to Table VII.

TABLE X

\section{CALCULATED PARTIAL PRESSURES OF MONOMERIC AND DIMERIC CESIUM IODIDE}

\begin{tabular}{|c|c|c|c|c|}
\hline $\begin{array}{l}\text { Temp. } \\
\text { (K) }\end{array}$ & $\begin{array}{c}\mathbf{P}_{\text {monomer }} \\
\text { (atm) }\end{array}$ & $\begin{array}{l}P_{\text {dimer }} \\
\text { (atm) }\end{array}$ & $\begin{array}{l}\mathbf{P}_{\text {total }} \\
\text { (atm) }\end{array}$ & $\begin{array}{c}100 X \\
P_{\text {dimer }} / \mathbf{P}_{\text {monomer }} \\
(\mathbf{a t m})\end{array}$ \\
\hline 300 & $1.83 \times 10^{-20}$ & $4.80 \times 10^{-83}$ & $1.83 \times 10^{-20}$ & $2.62 \times 10^{-6}$ \\
\hline 400 & $4.60 \times 10^{-18}$ & $1.33 \times 10^{-22}$ & $4.60 \times 10^{-18}$ & $2.89 \times 10^{-8}$ \\
\hline 500 & $4.56 \times 10^{-18}$ & $2.10 \times 10^{-10}$ & $4.56 \times 10^{-18}$ & 0.0460 \\
\hline 600 & $9.11 \times 10^{-10}$ & $2.54 \times 10^{-12}$ & $9.13 \times 10^{-10}$ & 0.279 \\
\hline 700 & $1.95 \times 10^{-7}$ & $1.90 \times 10^{-8}$ & $1.97 \times 10^{-7}$ & 0.974 \\
\hline 800 & $1.04 \times 10^{-6}$ & $2.49 \times 10^{-7}$ & $1.06 \times 10^{-8}$ & 2.39 \\
\hline 900 & $2.19 \times 10^{-4}$ & $1.02 \times 10^{-8}$ & $2.29 \times 10^{-4}$ & 4.67 \\
\hline 1000 & $1.74 \times 10^{-8}$ & $9.64 \times 10^{-6}$ & $1.83 \times 10^{-8}$ & 5.56 \\
\hline 1100 & $9.12 \times 10^{-8}$ & $5.69 \times 10^{-4}$ & $9.69 \times 10^{-3}$ & 6.24 \\
\hline 1200 & $3.54 \times 10^{-2}$ & $2.38 \times 10^{-8}$ & $3.78 \times 10^{-2}$ & 6.73 \\
\hline 1300 & 0.109 & $7.65 \times 10^{-8}$ & 0.116 & 7.04 \\
\hline 1400 & 0.279 & $2.01 \times 10^{-3}$ & 0.299 & 7.19 \\
\hline 1500 & 0.621 & $4.49 \times 10^{-2}$ & 0.666 & 7.23 \\
\hline 1600 & 1.23 & $8.84 \times 10^{-2}$ & 1.32 & 7.17 \\
\hline 1700 & 2.23 & 0.157 & 2.38 & 7.04 \\
\hline 1800 & 3.72 & 0.256 & 3.98 & 6.86 \\
\hline 1900 & 5.84 & 0.388 & 6.22 & 6.65 \\
\hline 2000 & 8.67 & 0.555 & 9.22 & 6.40 \\
\hline
\end{tabular}




\section{TABLE XI}

THERMODYNAMICS OF FORMATION OF MONOMERIC CESIUM IODIDE (g)

\begin{tabular}{r}
$\begin{array}{c}\text { Temp. } \\
\text { (K) }\end{array}$ \\
\hline \\
298.15 \\
300.00 \\
400.00 \\
500.00 \\
600.00 \\
700.00 \\
800.00 \\
900.00 \\
1000.00 \\
1100.00 \\
1200.00 \\
1300.00 \\
1400.00 \\
1500.00 \\
1600.00 \\
1700.00 \\
1800.00 \\
1900.00 \\
2000.00 \\
2100.00 \\
2200.00 \\
2300.00 \\
2400.00 \\
2500.00 \\
2600.00 \\
2700.00 \\
2800.00 \\
2900.00 \\
3000.00
\end{tabular}

\begin{tabular}{c}
$\Delta \mathbf{H}_{\mathbf{f}}^{\mathbf{9}}$ \\
\hline (kcal/mole) \\
\hline-37.600 \\
-37.609 \\
-40.560 \\
-46.168 \\
-46.455 \\
-46.736 \\
-47.017 \\
-47.295 \\
-63.652 \\
-63.684 \\
-63.714 \\
-63.742 \\
-63.769 \\
-63.792 \\
-63.815 \\
-63.837 \\
-63.859 \\
-63.880 \\
-63.903 \\
-63.928 \\
-63.956 \\
-63.988 \\
-64.026 \\
-64.070 \\
-64.123 \\
-64.187 \\
-64.262 \\
-64.350 \\
-64.454
\end{tabular}

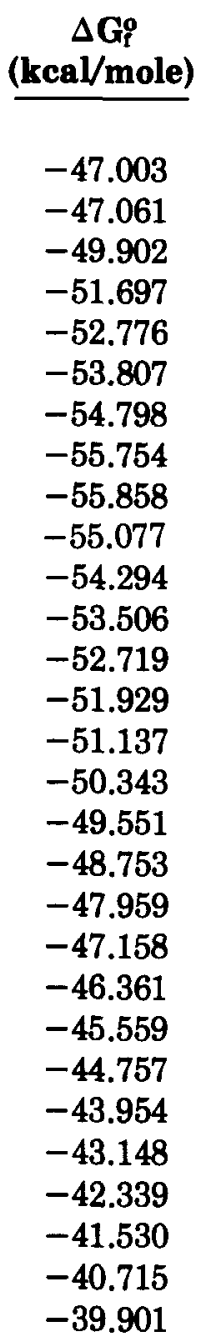


TABLE XII

THERMODYNAMICS OF FORMATION OF DIMERIC CESIUM IODIDE (g)

Temp.

(K)

298.15

300.00

400.00

500.00

600.00

700.00

800.00

900.00

1000.00

1100.00

1200.00

1300.00

1400.00

1500.00

1600.00

1700.00

1800.00

1900.00

2000.00

2100.00

2200.00

2300.00

2400.00

2500.00

2600.00

2700.00

2800.00

2900.00

3000.00 $\underset{\text { (keaV/mole) }}{\Delta \text { til }}$

$-110.200$

$-110.215$

$-115.932$

$-126.970$

$-127.367$

$-127.761$

$-128.157$

$-128.553$

$-161.114$

$-161.026$

$-160.943$

$-160.859$

$-160.781$

$-160.701$

$-160.626$

$-160.555$

$-160.489$

$-160.429$

$-160.379$

$-160.339$

$-160.313$

$-160.300$

$-160.306$

$-160.334$

$-160.385$

$-160.464$

$-160.574$

$-160.716$

$-160.900$

$$
\begin{gathered}
\Delta G_{\mathrm{f}} \\
\text { (kcal/mole) } \\
\hline-120.355 \\
-120.418 \\
-123.226 \\
-123.991 \\
-123.358 \\
-122.659 \\
-121.903 \\
-121.098 \\
-118.605 \\
-114.359 \\
-110.121 \\
-105.888 \\
-101.664 \\
-97.444 \\
-93.229 \\
-89.018 \\
-84.815 \\
-80.609 \\
-76.412 \\
-72.209 \\
-68.017 \\
-63.821 \\
-59.627 \\
-55.433 \\
-51.237 \\
-47.034 \\
-42.832 \\
-38.625 \\
-34.414
\end{gathered}
$$

\begin{tabular}{|c|c|c|c|}
\hline Frequencies & Degeneracy & Ref. 56" & This Calculation \\
\hline$v_{1}$ & 1 & $2933(58)$ & $2971.3(63)$ \\
\hline$v_{2}$ & 1 & $1252(58)$ & $1250.8(59)$ \\
\hline$v_{8}$ & 1 & $533(58,59)$ & $533.2(59)$ \\
\hline$u_{4}$ & 2 & $3060(58,60,62)$ & $3060.1(62,64)$ \\
\hline$v_{6}$ & 2 & $1436(61)$ & $1434.7(65,66,67)$ \\
\hline$v_{0}$ & 2 & $882(59,60)$ & $882.7(68)$ \\
\hline
\end{tabular}

TABLE XIII

\section{VIBRATIONAL FREQUENCIES OF METHYL IODIDE*}

Numbers in parentheses indicate the references that pertain to the given frequency. The frequencies used in Ref. 56 had been recommended in the review by Shimanouchi." 
TABLE XIV

IDEAL GAS THERMODYNAMIC FUNCTIONS OF METHYL IODIDE

\begin{tabular}{|c|c|c|c|c|}
\hline $\begin{array}{l}\text { Temp. } \\
\text { (K) }\end{array}$ & $\begin{array}{c}\mathbf{C}_{\mathfrak{p}}^{\mathbf{o}} \\
\text { (gibbs/mole) }\end{array}$ & $\begin{array}{c}\mathbf{S}_{\mathbf{T}}^{v} \\
\text { (gibbs/mole) }\end{array}$ & $\begin{array}{c}-\left(F_{T}^{o}-H_{2009}^{o}\right) / T \\
\text { (gibbs/mole) }\end{array}$ & $\underset{\text { (kcal/mole) }}{\mathrm{H}_{\mathrm{T}}^{\mathrm{P}}-\mathrm{H}_{200}^{2}}$ \\
\hline 0.00 & 0.000 & 0.000 & Infinite & -2.585 \\
\hline 100.00 & 8.005 & 51.012 & 68.905 & -1.789 \\
\hline 200.00 & 8.923 & 56.780 & 61.540 & -0.952 \\
\hline 298.15 & 10.536 & 60.631 & 60.631 & 0.000 \\
\hline 300.00 & 10.569 & 60.697 & 60.631 & 0.019 \\
\hline $400: 00$ & 12.333 & 63.981 & 61.067 & 1.165 \\
\hline 500.00 & 13.917 & 66.907 & 61.948 & 2.480 \\
\hline 600.00 & 15.274 & 69.568 & 62.999 & 3.941 \\
\hline 700.00 & 16.444 & 72.012 & 64.115 & 5.528 \\
\hline 800.00 & 17.465 & 74.276 & 65.245 & 7.225 \\
\hline 900.00 & 18.364 & 76.386 & 66.367 & 9.017 \\
\hline 1000.00 & 19.155 & 78.363 & 67.469 & 10.894 \\
\hline 1100.00 & 19.852 & 80.222 & 68.545 & 12.845 \\
\hline 1200.00 & 20.464 & 81.976 & 69.591 & 14.862 \\
\hline 1300.00 & 21.001 & 83.636 & 70.609 & 16.936 \\
\hline 1400.00 & 21.473 & 85.210 & 71.596 & 19.060 \\
\hline 1500.00 & 21.886 & 86.706 & 72.554 & 21.228 \\
\hline 1600.00 & 22.249 & 88.130 & 73.483 & 23.435 \\
\hline 1700.00 & 22.569 & 89.489 & 74.385 & 25.677 \\
\hline 1800.00 & 22.852 & 90.787 & 75.260 & 27.948 \\
\hline 1900.00 & 23.102 & 92.029 & 76.110 & 30.246 \\
\hline 2000.00 & 23.324 & 93.220 & 76.936 & 32.567 \\
\hline 2100.00 & 23.521 & 94.363 & 77.739 & 34.910 \\
\hline 2200.00 & 23.697 & 95.461 & 78.520 & 37.271 \\
\hline 2300.00 & 23.855 & 96.518 & 79.280 & 39.649 \\
\hline 2400.00 & 23.997 & 97.537 & 80.019 & 42.042 \\
\hline 2500.00 & 24.125 & 98.519 & 80.740 & 44.448 \\
\hline 2600.00 & 24.240 & 99.467 & 81.442 & 46.866 \\
\hline 2700.00 & 24.345 & 100.384 & 82.127 & 49.295 \\
\hline 2800.00 & 24.439 & 101.271 & 82.795 & 51.735 \\
\hline 2900.00 & 24.526 & 102.130 & 83.447 & 54.183 \\
\hline 3000.00 & 24.604 & 102.963 & 84.083 & 56.640 \\
\hline
\end{tabular}


TABLE XV

THERMODYNAMICS OF FORMATION OF METHYL IODIDE

\begin{tabular}{|c|c|c|}
\hline $\begin{array}{c}\text { Temp. } \\
\text { (K) }\end{array}$ & $\begin{array}{c}\Delta H_{i} \\
\text { (kcal/mole) }\end{array}$ & $\begin{array}{c}\Delta G_{\mathrm{f}}^{\text {p }} \\
\text { (kcal/mole) }\end{array}$ \\
\hline 298.15 & 3.300 & 3.723 \\
\hline 300.00 & 3.284 & 3.726 \\
\hline 400.00 & 0.557 & 4.063 \\
\hline 500.00 & -5.258 & 5.505 \\
\hline 600.00 & -5.673 & 7.698 \\
\hline 700.00 & -6.013 & 9.953 \\
\hline 800.00 & -6.285 & 12.253 \\
\hline 900.00 & -6.500 & 14.584 \\
\hline 1000.00 & -6.658 & 16.935 \\
\hline 1100.00 & -6.773 & 19.302 \\
\hline 1200.00 & -6.848 & 21.674 \\
\hline 1300.00 & -6.893 & 24.054 \\
\hline 1400.00 & -6.912 & 26.437 \\
\hline 1500.00 & -6.913 & 28.818 \\
\hline 1600.00 & -6.900 & 31.200 \\
\hline 1700.00 & -6.871 & 33.580 \\
\hline 1800.00 & -6.833 & 35.958 \\
\hline 1900.00 & -6.785 & 38.333 \\
\hline 2000.00 & -6.731 & 40.706 \\
\hline 2100.00 & -6.673 & 43.078 \\
\hline 2200.00 & -6.612 & 45.448 \\
\hline 2300.00 & -6.547 & 47.810 \\
\hline 2400.00 & -6.482 & 50.175 \\
\hline 2500.00 & -6.418 & 52.532 \\
\hline 2600.00 & -6.352 & 54.889 \\
\hline 2700.00 & -6.289 & 57.242 \\
\hline 2800.00 & -6.225 & 59.597 \\
\hline 2900.00 & -6.164 & 61.946 \\
\hline 3000.00 & -6.105 & 64.291 \\
\hline
\end{tabular}


TABLE XVI

IDEAL GAS THERMODYNAMIC FUNCTIONS OF CARBONYL IODIDE

\begin{tabular}{|c|c|c|c|c|}
\hline $\begin{array}{l}\text { Temp. } \\
\text { (K) }\end{array}$ & $\begin{array}{c}\mathrm{C}_{\mathrm{p}}^{o} \\
\text { (gibbs/mole) }\end{array}$ & $\begin{array}{c}\mathbf{S}_{\mathrm{T}}^{o} \\
\text { (gibbs/mole) }\end{array}$ & $\begin{array}{c}-\left(\mathbf{F}_{T}^{o}-\mathbf{H}_{2000}^{o}\right) / \mathbf{T} \\
(\mathrm{gibbs} / \mathrm{mole})\end{array}$ & $\underset{\text { (kcal/mole) }}{\mathbf{H}_{\mathrm{T}}^{\mathrm{o}}-\mathbf{H}_{208}^{\mathrm{o}}}$ \\
\hline 0.00 & 0.000 & 0.000 & Infinite & -3.600 \\
\hline 100.00 & 10.549 & 63.616 & 90.775 & -2.716 \\
\hline 200.00 & 14.025 & 72.098 & 79.457 & -1.472 \\
\hline 298.15 & 15.760 & 78.063 & 78.063 & 0.000 \\
\hline 300.00 & 15.782 & 78.160 & 78.063 & 0.029 \\
\hline 400.00 & 16.712 & 82.839 & 78.695 & 1.658 \\
\hline 500.00 & 17.325 & 86.638 & 79.915 & 3.361 \\
\hline 600.00 & 17.784 & 89.839 & 81.310 & 5.118 \\
\hline 700.00 & 18.142 & 92.609 & 82.730 & 6.915 \\
\hline 800.00 & 18.426 & 95.051 & 84.121 & 8.744 \\
\hline 900.00 & 18.652 & 97.234 & 85.459 & 10.598 \\
\hline 1000.00 & 18.834 & 99.209 & 86.737 & 12.473 \\
\hline 1100.00 & 18.980 & 101.012 & 87.954 & 14.364 \\
\hline 1200.00 & 19.100 & 102.668 & 89.112 & 16.268 \\
\hline 1300.00 & 19.198 & 104.201 & 90.214 & 18.183 \\
\hline 1400.00 & 19.279 & 105.627 & 91.265 & 20.107 \\
\hline 1500.00 & 19.347 & 106.959 & 92.267 & 22.038 \\
\hline 1600.00 & 19.404 & 108.210 & 93.225 & 23.976 \\
\hline 1700.00 & 19.453 & 109.388 & 94.141 & 25.919 \\
\hline 1800.00 & 19.495 & 110.501 & 95.020 & 27.866 \\
\hline 1900.00 & 19.531 & 111.556 & 95.862 & 29.818 \\
\hline 2000.00 & 19.562 & 112.558 & 96.672 & 31.772 \\
\hline 2100.00 & 19.589 & 113.514 & 97.452 & 33.730 \\
\hline 2200.00 & 19.613 & 114.425 & 98.203 & 35.690 \\
\hline 2300.00 & 19.634 & 115.298 & 98.927 & 37.652 \\
\hline 2400.00 & 19.652 & 116.134 & 99.627 & 39.617 \\
\hline 2500.00 & 19.669 & 116.936 & 100.303 & 41.583 \\
\hline 2600.00 & 19.683 & 117.708 & 100.958 & 43.550 \\
\hline 2700.00 & 19.697 & 118.451 & 101.592 & 45.519 \\
\hline 2800.00 & 19.708 & 119.168 & 102.207 & 47.490 \\
\hline 2900.00 & 19.719 & 119.859 & 102.804 & 49.461 \\
\hline 3000.00 & 19.729 & 120.528 & 102.384 & 51.433 \\
\hline
\end{tabular}


TABLE XVII

THERMODYNAMICS OF FORMATION OF CARBONYL IODIDE

$\begin{array}{cccc}\begin{array}{c}\text { Temp. } \\ \text { (K) }\end{array} & \begin{array}{c}\Delta \mathbf{H}_{\mathbf{q}}^{\mathbf{o}} \\ \text { (kcal/mole) }\end{array} & \begin{array}{c}\Delta \mathbf{G}_{\mathbf{f}}^{\mathbf{9}} \\ \text { (kcal/mole) }\end{array} \\ 298.15 & & -13.288 \\ 300.00 & -6.000 & -13.333 \\ 400.00 & -6.005 & -15.597 \\ 500.00 & -10.150 & -15.962 \\ 600.00 & -20.654 & -15.035 \\ 700.00 & -20.550 & -14.122 \\ 800.00 & -20.466 & -13.222 \\ 900.00 & -20.396 & -12.328 \\ 1000.00 & -20.340 & -11.441 \\ 1100.00 & -20.289 & -10.558 \\ 1200.00 & -20.248 & -9.679 \\ 1300.00 & -20.213 & -8.801 \\ 1400.00 & -20.184 & -7.926 \\ 1500.00 & -20.160 & -7.054 \\ 1600.00 & -20.142 & -6.181 \\ 1700.00 & -20.126 & -5.309 \\ 1800.00 & -20.114 & -4.440 \\ 1900.00 & -20.108 & -3.568 \\ 2000.00 & -20.104 & -2.698 \\ 2100.00 & -20.105 & -1.828 \\ 2200.00 & -20.108 & -0.956 \\ 2300.00 & -20.118 & -0.088 \\ 2400.00 & -20.130 & 0.786 \\ 2500.00 & -20.146 & 1.660 \\ 2600.00 & -20.167 & 2.532 \\ 2700.00 & -20.193 & 3.407 \\ 2800.00 & -20.223 & 4.282 \\ 2900.00 & -20.255 & 5.158 \\ 3000.00 & -20.294 & 6.035\end{array}$


TABLE XVIII

IDEAL GAS THERMODYNAMIC FUNCTIONS OF CESIUM HYDRIDE

\begin{tabular}{|c|c|c|c|c|}
\hline $\begin{array}{c}\text { Temp. } \\
(\mathbf{K})\end{array}$ & $\begin{array}{c}C_{\mathrm{p}}^{o} \\
\text { (gibbs/mole) }\end{array}$ & $\begin{array}{c}\mathbf{S}_{\mathrm{T}}^{o} \\
\text { (gibbs/mole) }\end{array}$ & $\begin{array}{r}-\left(F_{\mathrm{T}}^{\mathrm{o}}-\mathbf{H}_{28 \mathrm{~g}}^{\mathrm{o}}\right) / \mathrm{T} \\
(\mathrm{gibbs} / \mathrm{mole})\end{array}$ & $\begin{array}{c}\mathrm{H}_{\mathrm{T}}^{\circ}-\mathbf{H}_{208}^{\circ} \\
(\mathbf{k c a l} / \mathrm{mole})\end{array}$ \\
\hline 0.00 & 0.000 & 0.000 & Infinite & -2.114 \\
\hline 100.00 & 6.964 & 43.625 & 57.832 & -1.421 \\
\hline 200.00 & 7.127 & 48.482 & 52.078 & -0.719 \\
\hline 298.15 & 7.542 & 51.402 & 51.402 & 0.000 \\
\hline 300.00 & 7.551 & 51.449 & 51.402 & 0.014 \\
\hline 400.00 & 7.959 & 53.679 & 51.703 & 0.790 \\
\hline 500.00 & 8.265 & 55.490 & 52.285 & 1.602 \\
\hline 600.00 & 8.486 & 57.017 & 52.950 & 2.440 \\
\hline 700.00 & 8.649 & 58.338 & 53.627 & 3.297 \\
\hline 800.00 & 8.774 & 59.502 & 54.290 & 4.169 \\
\hline 900.00 & 8.873 & 60.541 & 54.928 & 5.051 \\
\hline 1000.00 & 8.954 & 61.480 & 55.537 & 5.943 \\
\hline 1100.00 & 9.024 & 61.337 & 56.117 & 6.842 \\
\hline 1200.00 & 9.086 & 63.125 & 56.669 & 7.747 \\
\hline 1300.00 & 9.142 & 63.854 & 57.194 & 8.659 \\
\hline 1400.00 & 9.194 & 64.534 & 57.694 & 9.576 \\
\hline 1500.00 & 9.242 & 65.170 & 58.171 & 10.498 \\
\hline 1600.00 & 9.289 & 65.768 & 58.628 & 11.424 \\
\hline 1700.00 & 9.334 & 66.332 & 59.064 & 12.355 \\
\hline 1800.00 & 9.377 & 66.867 & 59.483 & 13.291 \\
\hline 1900.00 & 9.420 & 67.375 & 59.885 & 14.231 \\
\hline 2000.00 & 9.463 & 67.859 & 60.272 & 15.175 \\
\hline 2100.00 & 9.505 & 68.322 & 60.644 & 16.123 \\
\hline 2200.00 & 9.547 & 68.765 & 61.003 & 17.076 \\
\hline 2300.00 & 9.588 & 69.190 & 61.350 & 18.033 \\
\hline 2400.00 & 9.630 & 69.599 & 61.685 & 18.994 \\
\hline 2500.00 & 9.673 & 69.993 & 62.010 & 19.959 \\
\hline 2600.00 & 9.715 & 70.374 & 62.324 & 20.928 \\
\hline 2700.00 & 9.758 & 70.741 & 62.629 & 21.902 \\
\hline 2800.00 & 9.801 & 71.097 & 62.925 & 22.880 \\
\hline 2900.00 & 9.844 & 71.441 & 63.213 & 23.862 \\
\hline 3000.00 & 9.888 & 71.776 & 63.493 & 24.848 \\
\hline
\end{tabular}


TABLE XIX

THERMODYNAMICS OF FORMATION OF CESIUM HYDRIDE

$\begin{array}{cccc}\begin{array}{c}\text { Temp. } \\ \text { (K) }\end{array} & \begin{array}{c}\Delta \mathbf{H}_{\mathbf{q}}^{\mathbf{9}} \\ \text { (kcal/mole) }\end{array} & \begin{array}{c}\Delta \mathbf{G}_{\mathbf{q}}^{\mathbf{9}} \\ \text { (kcal/mole) }\end{array} \\ 298.15 & & \\ 300.00 & 27.835 & 23.229 \\ 400.00 & 27.828 & 23.201 \\ 500.00 & 26.996 & 21.873 \\ 600.00 & 26.709 & 20.627 \\ 700.00 & 26.445 & 19.434 \\ 800.00 & 26.222 & 18.282 \\ 900.00 & 26.000 & 17.163 \\ 1000.00 & 25.787 & 16.072 \\ 1100.00 & 9.499 & 15.825 \\ 1200.00 & 9.539 & 16.455 \\ 1300.00 & 9.581 & 17.082 \\ 1400.00 & 9.623 & 17.705 \\ 1500.00 & 9.665 & 18.326 \\ 1600.00 & 9.707 & 18.943 \\ 1700.00 & 9.745 & 19.557 \\ 1800.00 & 9.782 & 20.171 \\ 1900.00 & 9.818 & 20.779 \\ 2000.00 & 9.851 & 21.388 \\ 2100.00 & 9.880 & 21.993 \\ 2200.00 & 9.902 & 22.600 \\ 2300.00 & 9.920 & 23.202 \\ 2400.00 & 9.933 & 23.808 \\ 2500.00 & 9.937 & 24.410 \\ 2600.00 & 9.930 & 25.012 \\ 2700.00 & 9.914 & 25.617 \\ 2800.00 & 9.886 & 26.223 \\ 2900.00 & 9.845 & 26.827 \\ 3000.00 & 9.789 & 27.435 \\ & 9.716 & 28.045\end{array}$

